\title{
Conditional Conservatism and the Cost of Equity Capital: Information Precision and Information Asymmetry Effects
}

\author{
Gary C. Biddle ${ }^{1}$, Mary L. Z. $\mathrm{Ma}^{2}$, Feng $\mathrm{Wu}^{3}$ \\ ${ }^{1}$ Faculty of Business and Economics, the University of Hong Kong \\ ${ }^{2}$ School of Administrative Studies, York University \\ ${ }^{3}$ School of Accounting and Finance, the Hong Kong Polytechnic University \\ Correspondence: Mary L. Z. Ma, School of Administrative Studies, York University, Atkinson College, 204A, 4700 \\ Keele Street, Toronto, ON M3J 1P3, Canada.
}

Received: November 2, 2015

Accepted: November 16, $2015 \quad$ Available online: November 30, 2015

doi:10.11114/afa.v2i1.1225

URL: http://dx.doi.org/10.11114/afa.v2i1.1225

\begin{abstract}
Prior studies report negative or insignificant relations between conditional conservatism and the cost of equity capital, arguing that conservatism reduces information risk. Using accounting-based conditional conservatism proxies, however, we find a significantly positive association between conditional conservatism and the cost of equity. This positive relation operates via improving information precision about negative earnings shocks and generally inflating information asymmetry among investors, both of which increase the cost of equity. We further find that the cost of equity effect of conditional conservatism disappears in the period after the enactment of the Sarbanes-Oxley Act (SOX), consistent with the notion that nationwide improvement of information precision about negative news and diminished information asymmetry are engendered by the SOX regulation. This study adds to researches on conditional conservatism, SOX, and the cost of equity, and also has policy implications.
\end{abstract}

Keywords: conditional conservatism, cost of equity capital, asset pricing test, Sarbanes-Oxley Act (SOX)

\section{Introduction}

Conditional conservatism is a longstanding feature of financial reporting characterized by the asymmetric timely recognition of bad earnings news relative to good news (Note 1). This more timely loss recognition has been explained as arising from debtholders' demands for information regarding borrowers' net liquidation values, thus enabling timely actions to protect debtholders' interests. The contracting benefit of conservative accounting, however, may come at the expense of its valuation role especially in the stock market (Armstrong, Guay, \& Weber, 2010). Recently, the Financial Accounting Standards Board [FASB] and the International Accounting Standards Board [IASB] have removed conservatism from their conceptual framework, arguing that conservative accounting induces information asymmetries that reduce shareholders' insights into future cash flows from growth options. Johnstone (in press) analytically shows that even in cases where information does bring greater precision, the precision about bad news could lower expected payoffs and thus increase the equity financing cost. These arguments suggest that timely loss recognition may increase the cost of equity by affecting information precision and information asymmetry.

Little prior evidence exists regarding this contention. However, several studies provide some hints about the possible information precision and information asymmetry effects of conditional conservatism. Ball, Jayaraman, and Shivakumar (2012) find that fair value accounting (FVA) increases information asymmetry; as conditional conservatism approximates FVA for net assets at bad times, the evidence suggests that conditional conservatism may similarly increase the cost of equity via enlarging information asymmetry. Kothari, Shu, and Wysocki (2009) report that negative news released by management, analysts, and the business press increases the cost of capital, and Rogers, Skinner, and Buskirk (2009) document that sporadic managerial forecasts of unexpected bad news increase market uncertainty. Since conditional conservatism reveals unexpected negative news, it could possibly increase market risk and thus the cost of equity. Contrary to the implications of these studies, literatures on conditional conservatism and the cost of equity document either a negative relation (e.g., Li, 2010; Garcia Lara, Garcia Osma, \& Penalva, 2011) or an insignificant one (e.g., Francis, LaFond, Olsson, \& Schipper, 2004). Therefore, the association between conditional conservatism and the cost of equity capital is still an open empirical question. 
This study is thus motivated to examine how conditional conservatism affects the cost of equity via the effects of information precision (i.e., more precisely revealing bad news) and information asymmetry. Most analytical studies demonstrate that conditional conservatism improves information quality by providing more accurate negative earnings signals (e.g., Gao, 2011; Fan \& Zhang, 2012). The main argument is that increased information quality through timely bad earnings news reporting reduces investors' uncertainty regarding expected future cash flows and the cost of equity capital (Guay \& Verrecchia, 2007; Lambert, Leuz, \& Verrecchia, 2007), which underlies prior studies on the relation between conditional conservatism and the cost of equity. However, existing evidence fails to provide consistent empirical supports for this argument because both negative and insignificant conservatism-cost of capital relations are documented, as mentioned above. We propose that the lack of considerations in two dimensions of the implication of information quality may contribute to the mixed evidence. Specifically, improved information quality by conditional conservatism may generate both a precision effect via changing the average precision level of information and an asymmetry effect through increasing information asymmetry among market participants. With regard to the information precision effect, Johnstone (in press) states that although conditional conservatism increases information certainty, it conveys unexpected bad earnings news and lower expected payoffs, and a more precise revealing of bad news can increase the cost of equity. This suggests that the more precise bad news shocks are conveyed by conditional conservatism, the more possible that the relation between conditional conservatism and the cost of equity is positive.

For the information asymmetry effect, existing studies ignore this channel because they assume an efficient and perfectly competitive equity market that only allows the information precision effect of conditional conservatism. Relaxing this assumption, conditional conservatism can also increase the cost of capital through the information asymmetry effect. In particular, despite enhancing information quality, conditional conservatism can nevertheless increase information asymmetry and heterogeneity of opinions among analysts and investors by inducing unexpected negative information shocks. Earlier theoretical works concur that accelerating public disclosures and enhancing information quality can trigger private information acquisition by sophisticated investors, which escalates information asymmetry among investors in general (Kim \& Verrecchia, 1991; Demski \& Feltham, 1994; McNichols \& Trueman, 1994). Recent theoretical and empirical studies argue and provide confirming evidence that enhanced information quality increases equity cost by generating the information asymmetry effect, especially when the market is less than perfectly competitive and/or illiquid (Armstrong, Core, Taylor, \& Verrecchia, 2011; Gow, Taylor, \& Verrecchia, 2011; Lambert, Leuz, \& Verrecchia, 2012). Consistently, several other studies report a positive relation between conditional conservatism and analyst forecast errors (Mensah, Song, \& Ho, 2004; Louis, Lys, \& Sun, 2014). Therefore, when the market is imperfect beyond a threshold, the information asymmetry effect of conditional conservatism may enhance the potential information precision effect in increasing equity cost, whereas in a more perfect market, the information asymmetry effect does not work. Overall, the above analysis suggests that the conditional conservatism and equity cost relation through information quality hinges on the combined effects of information precision and information asymmetry, which are to date empirically unexplored.

To examine the relation between conditional conservatism and the cost of equity that operates via the information precision and information asymmetry effects, it is crucial to insulate the measures for conditional conservatism and the cost of equity from the influences of concurrent stock price information and cash flow shocks. Prior studies on this line of research use stock price-based conditional conservatism measures such as the Basu (1997) measure in Francis et al. (2004) and the CR ratio in Garcia Lara et al. (2011). These measures not only assume market efficiency and perfect competition, which are inconsistent with the tests for information effects of conditional conservatism, but also reflect cash flow news inherent in stock returns (Caskey \& Petersen, 2009), which may induce a mechanical (possibly negative) relation between conditional conservatism and equity return (Note 2). These measurement issues are potentially (at least partially) responsible for the mixed findings about the association between conditional conservatism and the cost of equity in prior studies. To mitigate the confounding effects, we employ an alternative accounting-based conditional conservatism proxy - the average of accumulated non-operational accruals and earnings skewness - to provide clearer inferences regarding the informational effects of conservatism, following Basu (1995), Givoly and Hyan (2000), and Zhang (2008). We also control for the impacts of cash flow shocks induced by conditional conservatism, which are impounded into and decrease the realized stock return, a proxy for expected return and cost of equity capital often used in prior studies. Specifically, we adjust the realized excess return by concurrent cash flow news and use it as our measure for the cost of equity as suggested by Vuolteenaho (2002), McInnis (2010), Botosan, Plumlee, \& Wen (2011), and Ogneva (2012) (Note 3).

Utilizing standard asset pricing tests including hedging portfolio analyses and multivariate regressions based on these measures, we find a significant positive relation between conditional conservatism and the expected stock return adjusted for cash flow news. In particular, a hedging strategy for conditional conservatism-sorted portfolios earns significantly positive excess returns, and firm-level Fama-MacBeth cross-sectional regressions yield significantly positive associations between conditional conservatism and future excess returns adjusted for cash flow news both 
before and after controlling for firm risk characteristics. Portfolio-level two-stage cross-sectional regressions further reveal that factor loadings on conditional conservatism are significantly positively associated with return spreads for conditional conservatism-sorted portfolios, implying that conditional conservatism is priced by market participants. These findings are in line with the notion that the effects of conditional conservatism on information precision and information asymmetry increase the cost of equity.

We conduct additional analyses to provide more direct supporting evidence regarding the information precision and information asymmetry effects of conditional conservatism on the cost of equity. We use the bid-ask spread to capture the information asymmetry effect and the magnitude of earnings downside risk to capture the information precision effect regarding negative earnings shocks. We find that larger conditional conservatism is generally associated with higher information asymmetry and higher precision about earnings downside risk. In addition, controlling information asymmetry and/or precision about negative earnings shocks in Fama-MacBeth regressions substantially reduces the conditional conservatism coefficients, consistent with our proposition that information precision and information asymmetry effects of conditional conservatism at least partially explain the positive association between conditional conservatism and the cost of equity.

The passage of the Sarbanes-Oxley Act of 2002 (SOX) offers a unique setting to further investigate the effects of information precision and information asymmetry on the positive relation between conditional conservatism and the cost of equity. SOX regulations are promulgated to increase financial reporting transparency, reduce information asymmetry, and improve market efficiency. In particular, the nationwide improvement of information precision about negative news and diminished information asymmetry engendered by SOX regulation holds the potential to mitigate the cross-sectional firm-specific effect of conditional conservatism on the cost of equity. We thus expect a weakened relation between conditional conservatism and the cost of equity following the enactment of SOX despite the fact that SOX increases conditional conservatism as shown in Lobo and Zhou (2006). Fama-MacBeth regressions for the periods before and after SOX give confirming evidence that the enhancing effect of conditional conservatism on the cost of equity has disappeared in the post-SOX period.

This study contributes to literatures on accounting conservatism, the cost of equity capital and SOX, and holds policy implications. First, utilizing conditional conservatism measures net of the influences from stock market and cash flow shocks, we provide original evidence supporting the notion that conditional conservatism reveals more precise information about unexpected negative earnings shocks and reduces expected payoffs, and also generates new information asymmetry among investors, both of which ultimately dampen stock prices and enhance the cost of equity. Our study thus extends prior research that draws only on one facet of the information effect of conservatism and documents mixed evidence of negative or insignificant associations between conservatism and the cost of equity (Francis et al., 2004; Li, 2010; Garcia Lara et al., 2011). Differing from these studies, we provide an opposite finding using refined measures and testing methods via a more comprehensive perspective regarding the information quality effect of conservatism.

Second, we provide evidence supporting Johnstone's (in press) argument that more precise information about bad earnings news can increase the cost of equity capital. We further identify information asymmetry as a channel for the observed positive relation between conditional conservatism and the cost of equity, which extends prior studies on the asset pricing effect of information asymmetry (Armstrong et al., 2011; Gow et al., 2011; Lambert, Leuz, \& Verrecchia, 2012). This also adds to the literature on the relation between conservatism and information asymmetry. Watts (2003), LaFond and Roychowdhury (2008), and LaFond and Watts (2008) argue that accounting conservatism mitigates deadweight losses arising from information asymmetry between firms and external shareholders. Extending this line of research, we document a significant positive relation between conditional conservatism and information asymmetry in general.

Third, this study contributes to the SOX literature by providing evidence that the positive relation between conditional conservatism and equity cost disappears following the implementation of SOX, which reconfirms that the relation operates through the informational effect of conservatism. Our research also lends credence to SOX's intended purpose to reduce information asymmetry and enhance information quality.

Finally, our study also has practical implications. It informs deliberations regarding the economic influence of accounting conservatism that the FASB and IASB recently removed as a fundamental characteristic of financial information in favor of neutrality. Our findings imply that conditional conservatism imposes costs on both stock market investors and managers, thus pointing to a legitimate yet neglected rationale for managers to disfavor conditional conservatism - it creates unexpected negative earnings shocks and generates new information asymmetry among investors, both of which enhance the cost of equity and dampens stock prices.

We proceed as follows. Section 2 describes prior literature and theory development. Section 3 explains our measures and research design. Section 4 reports the main testing results. Section 5 presents robustness checks, and Section 6 
concludes.

\section{Literature Review and Theory Development}

\subsection{The Information Precision Effect of Conditional Conservatism}

Most analytical studies demonstrate that conditional accounting conservatism improves information quality by providing more accurate signals (Fan \& Zhang, 2012), alleviating dysfunctional earnings manipulations (Chen, Hemmer, \& Zhang, 2007; Gao, 2011), limiting false signaling and free-riding by bad firms (Nan \& Wen, 2011), and promoting timely good news disclosures (Guay \& Verrecchia, 2007). Whereas Gigler, Kanodia, Sapra, and Venugopalan (2009) argue that conditional conservatism conveys news about income-decreasing events at the cost of downward-biased estimation and thus reduces its information content, Gao (2011) demonstrates that in the presence of managerial opportunism (e.g., earnings management), the optimal measurement rule is conservatism since it helps cancel off upward bias and leads to more accurate estimation than a neutrality convention (Gox \& Wagenhofer, 2009).

By focusing on improved information quality, prior empirical studies on conditional conservatism and the cost of equity report insignificant or negative relations between them (Francis et al., 2004; Li, 2010; Garcia Lara et al., 2011). Using Basu's (1997) conditional conservatism measure based on investors' asymmetric responses to good and bad earnings news, Francis et al. (2004) fail to find a significant association between conditional conservatism and the cost of equity. Also using Basu's (1997) measure, Li (2010) examines the cost of capital effect of conditional conservatism in international debt and equity market settings, and reports that firms domiciled in countries with more conservative reporting systems have lower cost of equity. Garcia Lara et al. (2011) also report a significantly negative relation by adopting a stock return-based conditional conservatism measure, the CR ratio.

These existing studies mainly employ the theoretical models of Hughes, Liu, and Liu (2007), Guay and Verrecchia (2007), and Lambert et al. (2007), and argue that more timely bad earnings news reporting via conservatism increases average information precision among investors about expected cash flows, which reduces the covariance between a firm's stock return and the market return and thus lowers the cost of equity capital. However, in a recent theoretical paper, Johnstone (in press) analytically demonstrates that the logic underlying these prior theories is misleading in the sense that (i) the best available information can sometimes leave decision makers less certain about future events, and (ii) even if better information precision brings greater certainty among investors, more precise bad news could lower expected payoffs and thus increase the cost of equity.

Consistent with Johnstone's (in press) argument, another pitfall in prior theoretical studies is that they only focus on covariance. Given unchanged covariance, if more precise information lowers investors' cash flow expectation, which is associated with macroeconomic trends, it may increase the cost of equity. For instance, if more precise information of timely earnings loss has a systematic economy-wide component by mirroring macroeconomic figures and/or projecting downward market-wide uncertainty into a firm's earnings numbers, then it should hold the potential to increase the cost of equity. Crawley (2012) indicates that aggregate conditional conservatism increases the response of macroeconomic indicators to negative economic news and enhances its negative relation with the federal funds rate. Jorgensen, $\mathrm{Li}$, and Sadkay (2012) argue (but do not directly test) that conditional conservatism increases aggregate earnings dispersion, which reflects systematic economic uncertainty and increases expected return. The evidence and reasoning suggest that more precise and timely information about bad news recognition has a systematic risk component, which goes hand in hand with its effect of lowering payoff expectations as suggested by Johnstone (in press) to increase the cost of equity capital. Moreover, conditional conservatism especially captures bad earnings news shocks, which are reflected in a large magnitude of negative shocks of earnings downside risk. Luo, Ma, and Wu (2014) show that earnings downside risk measured by the lower partial moment of earnings reflects macroeconomic downward trends and is positively associated with the cost of equity. Overall, the above analyses collectively suggest that conditional conservatism can increase the cost of equity due to more precision in revealing bad news of negative earnings shocks.

\subsection{The Information Asymmetry Effect of Conditional Conservatism}

Most prior studies relevant to the association between conditional conservatism and the cost of equity implicitly assume market efficiency and perfect competition (e.g., Francis et al., 2004; Hughes, Liu, \& Liu, 2007; Garcia Lara et al., 2011; Lambert et al., 2012). Specifically, Hughes et al. (2007) and Lambert et al. (2012) observe that under these assumptions, there is no opportunity for information asymmetry to influence the cost of equity and only information precision can be priced. For example, Hughes et al. (2007) argue that the pricing of asymmetric information in a competitive market as claimed by Easley and O'Hara (2004) is a "misperception". Without these assumptions, however, i.e., in a less perfectly competitive setting, information asymmetry may play a role in affecting the cost of equity. Several theoretical studies claim that public disclosures can trigger private information acquisition and increase opinion divergence and information asymmetries among investors (Kim \& Verrecchia, 1991; Demski \& Feltham, 1994; McNichols \& Trueman, 1994). Investors with an information advantage have a stronger influence on stock price, and investors with less 
sophisticated information processing ability and/or with an information disadvantage will thus require higher compensation to enter the market and to trade with better-informed counterparties (e.g., Diamond \& Verrecchia, 1991; Verrecchia, 2001; Easley, Hvidkjaer, \& O'Hara, 2002; Easley \& O'Hara, 2004). Consistent with this reasoning, recent empirical and theoretical works such as Gow et al. (2011) and Lambert et al. (2012) argue that higher precision of reported (earnings) information complements private information acquired by sophisticated investors (i.e., discourages them from acquiring private information), leading to higher opinion heterogeneity and more rather than less information asymmetry. Armstrong et al. (2011), Gow et al. (2011), and Akins, Ng, and Verdi (2012) document consistent evidence that information asymmetry increases the cost of capital when the market is less than perfectly competitive (Note 4).

While conditional conservatism increases information quality and thereby enhances outsiders' ability to verify information provided by insiders (Watts, 2003), this enhanced information precision can alternatively cause a greater heterogeneity of opinions and generate new information asymmetry among external shareholders as stock market investors are more sensitive to sporadic, unexpected, and negative earnings news (Rogers et al., 2009). Therefore, we expect that, on net, conditional conservatism increases information asymmetry and equity cost via its information asymmetry effect in less than perfectly competitive settings. When the market is imperfect beyond a certain level, the information asymmetry effect of conditional conservatism may add to its information precision effect and lead to a larger increase in equity cost, although this information asymmetry effect should be nonexistent in a perfect market.

In summary, given the fact that conditional conservatism leads to high information quality, high quality information may not necessarily lead to low cost of equity. The key insight is that conservative reporting reveals bad news more precisely. Such precise revealing of bad news could possibly increase the cost of equity by (i) inducing a pessimistic expectation of fundamental payoffs (the information precision effect) and (ii) entailing additional asymmetric information among investors (the information asymmetry effect), especially in an imperfect market. Prior studies on the relation between conservatism and the cost of equity capital largely neglect these two aspects inherent in the information quality effect of conditional conservatism. Our work is therefore set on investigating the relation between conditional conservatism and the cost of equity via these new informational perspectives.

\section{Measurements and Research Methodology}

Two necessary requirements for studying conditional conservatism and its relation with the cost of equity from the informational perspective are that (i) the conditional conservatism measure should be free of the confounding impact of stock market information and (ii) the realized equity return as a proxy for the ex ante cost of equity should be net of unexpected cash flow shocks ex post. The reason is that both considerations could possibly induce spurious results and biased inferences about the association between conditional conservatism and the cost of equity. Specifically, the conditional conservatism measure should not endogenously incorporate stock return data, which already impound the effects of information precision and information asymmetry and their feedbacks to firms' and investors' investment behaviors. This consideration is critical especially when the cost of equity is measured by stock returns; otherwise, a potential mechanical relation may arise by construction. For the same reason, it is important to control for unexpected cash flow shocks (cash flow news) embedded in realized stock returns when measuring investors' expected returns for equity investment. Prior evidence suggests that conditional conservatism is closely related to cash flow news (e.g., Callen, Segal, \& Hope, 2010; Kim \& Pevzner, 2010; Srivastava \& Sunder, 2011) that is reflected in stock prices (Note 5). Cash flow news may also subsume private information feedback (Gao \& Liang, 2011) and twist with the information asymmetry effect (Gow et al., 2011). Therefore, empirical tests involving equity returns without controlling for cash flow news may yield spurious inferences about the impact of conditional conservatism on the cost of equity.

For these reasons, we use realized excess stock returns that explicitly control for cash flow news to measure the cost of equity and employ accounting-based conditional conservatism measures immune from asset market influences. Both treatments are amenable to our research purpose of having a comprehensive examination of conditional conservatism's impact on equity cost from the perspectives of the information precision effect and information asymmetry effect. In this sense, our measures are supplements to rather than substitutes for existing proxies for conditional conservatism and the cost of equity.

\subsection{The Conditional Conservatism Measure}

In the main tests, our accounting-based conditional conservatism measure $C O N$ is defined as the average of relative accumulated non-operational accruals $\left(C O N \_A c m\right)$ and relative earnings skewness $\left(C O N \_S k e w\right)$. CON_Acm is negative one times the ratio of accumulated non-operating accruals to accumulated total assets, with both computed using a moving average of the current and prior two years for each firm-year observation, and

$$
\begin{aligned}
& \text { Non-operating accruals }=\text { Total accruals }-\triangle \text { accounts receivable (Compustat RECT) } \\
& \text { - Ainventories (Compustat INVT) - } \triangle \text { prepaid expenses (Compustat XPP) } \\
& \text { + Saccounts payable (Compustat AP) + Dtaxes payable (Compustat TXT) }
\end{aligned}
$$


This measure follows Givoly and Hayn (2000) and Zhang (2008) and captures bad earnings news reporting via non-operational accruals, for example, those arising from restructuring charges and asset write-downs. However, this is a noisy measure for conditional conservatism (Ryan, 2006). Presumably, it also captures unconditional conservatism (e.g., pooling vs. purchase accounting), (real) earnings management, the stock option expense, etc.

CON_Skew is negative one times the ratio of the sum of 10 and earnings skewness to the sum of 10 and operating cash flow (OCF) skewness, where skewness is estimated using a rolling window of 20 quarters with a minimum requirement of 12 quarters of data. This measure derives from Basu (1995) and adapts the negative skewness measure in Zhang (2008) to ensure that higher skewness indicates higher degree of conditional conservatism. We deflate earnings skewness by OCF skewness to control for the influence of shocks in the cash flow. Since CON_Acm and CON_Skew are both noisy proxies for conditional conservatism and may capture non-conservatism elements such as big baths, we use their average $C O N$ to help mitigate potential measurement errors. In robustness tests, we examine CON_Acm and CON_Skew separately. We also employ negative earnings skewness, Skew, defined as the difference between the skewnesses of OCF and earnings estimated over a 20-quarter rolling window (Callen et al., 2010), and CONA, defined as the average of Skew and CON_Acm, as alternative conditional conservatism measures for robustness checks.

\subsection{The Cost of Equity Measure}

Our cost of equity measure controls for the effect of cash flow news by subtracting it from realized excess stock returns, extending the methodology in McInnis (2010) and Ogneva (2012) (Note 6). Specifically, we calculate cash flow news $(\mathrm{Ne})$ as follows. First, we estimate earnings surprises (SURP) from a time-series earnings prediction model augmented by the economic determinants of earnings, assuming that annual earnings for firm $i$ follow an AR (1) process. We use a rolling window of five years to fit model (2) below by Fama and French (1997) industry classifications:

$$
E A R N_{i t+1}=\beta_{0}+\beta_{1} E A R N_{i t}+\beta_{2} S A L E_{i t}+\beta_{3} S I Z E_{i t}+\varepsilon_{i t+1}
$$

where $\operatorname{EARN}_{i t+1}\left(E A R N_{i t}\right)$ is earnings over book equity for the next (current) fiscal year, $S A L E_{i t}$ is sales over book value of total assets for the current fiscal year, and $S I Z E_{i t}$ is firm size measured as the natural logarithm of market equity at the current fiscal year-end.

Earnings surprise $S U R P_{i t+1}$ is then calculated as the difference between the actual and predicted EARN times the book value of equity, which is scaled by the market value of equity at the beginning of the month. We obtain cash flow news from monthly cross-sectional regressions of excess stock returns on contemporaneous earnings surprises using a linear OLS specification. Cash flow news $\left(N e_{i t+1}\right)$ is calculated as the product of $S U R P_{i t+1}$ and its estimated coefficient from the following models:

$$
\begin{aligned}
R_{i t+1}^{r a w} & =\alpha_{0}+\alpha_{1} S U R P_{i t+1}+\varepsilon_{i t+1} \\
N e_{i t+1} & =\dot{\alpha}_{1} S U R P_{i t+1}
\end{aligned}
$$

where $R^{\text {raw }}$ is monthly excess return and $\dot{\alpha}_{l}$ is the estimated $\alpha_{l}$ in model (3). We use the next month's excess return adjusted for cash flow news $R_{i t+1}$ as the cost of equity capital proxy (i.e., $R_{i t+1}=\alpha_{0}+\varepsilon_{i t+1}=R^{r a w}{ }_{i t+1}-N e_{i t+1}$ ).

\subsection{Measures for Information Precision and Information Precision}

Following the literature, we use three measures for information asymmetry: average bid-ask spread IRisk, average daily high and low spread HLSpread, and private information trading Itrade. IRisk is defined as the average daily percentage bid-ask spread over the 12 months prior to the current fiscal year-end, HLSpread refers to the average daily high and low spread over the 12 months prior to the current fiscal year-end calculated following Corwin and Schultz (2011), and Itrade is estimated as in Llorente, Michaely, Saar, and Wang (2002) and Ferreira and Laux (2007). Both IRisk and HLSpread reflect information asymmetry in general, while Itrade denotes information asymmetry arising from speculators' information hunting. We use IRisk in the main tests and employ HLSpread and Itrade in robustness checks.

Measuring the information precision associated with conditional conservatism is not as easy. The traditional measure for information precision (quality) is accrual quality Acc, the volatility of residual accruals estimated from an accrual prediction model. However, Acc reflects information precision of both and bad earnings news. Therefore, it cannot accurately capture the information precision of negative earnings shocks conveyed by conditional conservatism, which should be only relevant to the downside volatility of accruals or earnings. We thus adopt the following downside risk measures used in Luo et al. (2014), ERisk and AERisk, to capture the information precision of conditional conservatism about bad earnings shocks. ERisk refers to the downside risk of residual accruals from an accrual prediction model, and is calculated as the natural logarithm of the ratio of one plus the accrual root lower partial moment over one plus the accrual root upper partial moment (Note 7). Similarly, AERisk measures the downside risk of residual earnings estimated from an earnings prediction model, and calculated as the natural logarithm of the ratio of one plus the root lower partial moment of return on assets (ROA) over one plus the root upper partial moment of ROA. 
Both ERisk and AERisk are significantly positively associated with accrual quality Acc (as shown in Table 1 later). Luo et al. (2014) report that earnings and accrual downside risk measures are also positively associated with other available information quality measure such as predictability and timeliness, suggesting that they are valid measures for information precision of negative earnings shocks associated with conditional conservatism. Since accrual-based downside risk ERisk is the main source of earnings downside risk and drives its relation with the cost of capital (Luo et al. 2014), we use ERisk in our main tests, and use AERisk (and simple earnings volatility) in robustness checks.

\subsection{The Asset Pricing Methodology}

Our main approach to examining the relation between conditional conservatism and the cost of equity capital follows standard asset pricing methods including the hedging portfolio analysis, the firm-level Fama-MacBeth cross-sectional regression, and the portfolio-level two-stage cross-sectional regression (2SCSR) analysis, as elaborated below. We also employ other approaches such as the pooled OLS regression in robustness checks.

We first use a hedging portfolio approach that buys (sells) stocks with high (low) conditional conservatism measures to assess the association of conditional conservatism with the cost of equity (excess equity returns adjusted for cash flow news) (Note 8). Specifically, for each month, stocks are assigned to one of five portfolios based on a firm's most recent conditional conservatism measure CON, with at least four months lag and portfolio 1 (5) containing firms with the lowest (highest) level of CON. The monthly return difference between the highest (portfolio 5) and lowest (portfolio 1) CON portfolios is computed with a significantly positive (negative) mean difference indicating a positive (negative) relation between $\mathrm{CON}$ and the cost of equity capital.

To control for other factors that may influence the CON-return relation, we regress firm-specific excess returns adjusted for cash flow news on CON and other firm characteristics. We match annual CON estimates with monthly returns in the next 12 months starting four months after the fiscal year-end. For example, for firms with fiscal year $\mathrm{t}$ ending in December, we collect monthly returns data from April of calendar year $t+1$ to March of calendar year $t+2$. We estimate the following cross-sectional regression model and its simplified variations by month and then average the coefficient parameters following the procedures in Fama and MacBeth (1973):

$$
\begin{aligned}
R_{i t+1}-R_{\text {Ft }+1}= & \alpha+\beta_{1} \text { CON }_{i t}+\beta_{2} \text { Beta }_{i t}+\beta_{3} \text { Size }_{i t}+\beta_{4} \text { BM }_{i t}+\beta_{5} \text { Momentum }_{i t}+\beta_{6} T C A_{i t} \\
& +\beta_{7} \text { Acc }_{i t}+\beta_{8} \text { Low_Priced }_{i t}+\mu_{i t+1}
\end{aligned}
$$

where $C O N_{i t}$ is the conditional conservatism measure for stock $i$ in month $t, R_{i t+1}$ refers to return adjusted for cash flow news for stock $i$ in month $t+1, R_{F t+l}$ is the U.S. one-month T-bill rate in month $t+1$, Beta $a_{i t}$ refers to the beta of stock $i$ for month $t$ estimated as in Fama and French (1992), Size $e_{i t}$ is defined as the natural logarithm of market capitalization of stock $i$ for month $t$ as in Fama and French (1992), $B M_{i t}$ is the natural logarithm of the ratio of book to market equity of stock $i$ for month $t$ as in Fama and French (1992), Momentum ${ }_{i t}$ refers to the buy-and-hold return of stock $i$ for the 11-month period ending one month prior to the current month $t, T C A_{i t}$ is total accrual measured in the balance sheet approach scaled by total assets following Sloan (1996) (Note 9). $A c c_{i t}$ is the decile ranking of accrual quality from Kim and Qi (2010) and Ogneva (2012) (Note 10), and Low_Priced ${ }_{i t}$ is an indicator variable for returns with two adjacent prices of less than five U.S. dollars as defined in Kim and Qi (2010). Among the control variables, Beta, Size and BM are commonly accepted factors that affect expected stock returns. We include Momentum to ensure that the results are not attributable to conservative firms with previous negative returns. Since one $C O N$ component $\left(C O N \_A c m\right)$ is accrual-based, we control for $T C A$ and $A c c$ to ensure that the relation between conditional conservatism and equity returns is robust to the pricing effects of TCA and Acc (Khan, 2008; Ogneva, 2012; Kim \& Qi, 2010). Low_Priced is also controlled along with $A c c$ since penny stocks substantially impact Acc's pricing (Kim \& Qi, 2010). Following Lewellen, Nagel, and Shanken (2010), we include industry dummies in cross-sectional regressions to address the concern that missing industry effects may bias the coefficient estimates.

We further conduct a 2SCSR analysis on Fama-French 25 size and BM portfolios to examine possible risk-based asset pricing implications of conditional conservatism. In the first stage, we construct a conservatism factor RCON, which represents return on a zero-investment portfolio buying the top 20 percent of firms and selling the bottom 20 percent of firms sorted by CON, and estimate the multivariate betas from time-series regressions of excess returns for a portfolio of firms according to size and $\mathrm{BM}, R_{q t}-R_{F t}$, on contemporaneous portfolio returns to the Fama-French and momentum factors along with $R C O N$. The first-stage models are:

$$
\begin{array}{r}
R_{q t}-R_{F t}=b_{0}+b_{q, R M-R F}\left(R_{M t}-R_{F t}\right)+b_{q, S M B} S M B_{t}+b_{q, H M L} H M L_{t}+b_{q, R C O N} R C O N_{t}+\varepsilon_{q t} \\
R_{q t}-R_{F t}=b_{0}+b_{q, R M-R F}\left(R_{M t}-R_{F t}\right)+b_{q, S M B} S M B_{t}+b_{q, H M L} H M L_{t} \\
+b_{q, U M D} U M D_{t}+b_{q, R C O N} R C O N_{t}+\varepsilon_{q t}
\end{array}
$$


where $R_{q t}$ refers to average excess return on the size-BM portfolio $q$ in month $t, R C O N_{q t}$ is the return on $C O N$ factor as explained above, $R_{M t}-R_{F t}$ refers to the return on market portfolio (CRSP value-weighted) minus the risk free rate proxied by the U.S. one-month T-bill rate $R_{F t}, S M B_{t}$ is the return on a factor-mimicking hedge portfolio for size as in Fama and French (1993), $H M L_{t}$ is the return on a factor-mimicking hedge portfolio for BM as in Fama and French (1993), and $U M D_{t}$ refers to the return on a factor-mimicking hedge portfolio for momentum as in Carhart (1997).

The second stage estimates the cross-sectional regressions of mean excess factor returns on the factor loadings estimated in the first-stage time-series regressions as follows:

$$
\begin{gathered}
R_{q t}-R_{F t}=a_{0}+a_{1} b_{q, R M \_R F}+a_{2} b_{q, S M B}+a_{3} b_{q, H M L}+a_{4} b_{q, R C O N}+\eta_{q t} \\
R_{q t}-R_{F t}=a_{0}+a_{1} b_{q, R M \_R F}+a_{2} b_{q, S M B}+a_{3} b_{q, H M L}+a_{4} b_{q, U M D}+a_{5} b_{q, R C O N}+\eta_{q t}
\end{gathered}
$$

where $b_{q, R M_{-} R F}, b_{q, S M B}, b_{q, H M L}, b_{q, U M D}$, and $b_{q, R C O N}$ are factor loadings estimated in the first stage. If the estimated coefficients for $b_{q, R C O N}$ are significantly positive (negative), then $R C O N$ is deemed to reflect a priced factor with a positive (negative) risk premium.

\section{Data and the Relation between Conditional Conservatism and the Cost of Equity}

\subsection{Data and Descriptive Statistics}

Our sample consists of all common stocks traded on the NYSE, NASDAQ, and AMEX during the period from January 1986 to December 2008. Daily and monthly returns and the U.S. one-month T-bill rates are obtained from CRSP, with corresponding accounting data retrieved from COMPUSTAT. Conditional conservatism estimates are winsorized to the $1 \%$ and 99\% percentiles of Fama and French (1997) industry distributions for each fiscal year to abate potential biases from outliers. The final sample includes 62,833 firm-year observations with conditional conservatism estimates. Table 1 reports descriptive statistics for variables used in the main tests. Panel A shows that the means (medians) of $C O N$ and its two components, CON_Acm and CON_Skew, are -0.5035 (-0.5129), 0.0085 (0.0116), and -1.0155 (-1.0303), respectively (Note 11). Panel B indicates that the Pearson and Spearman correlations of CON with CON_Skew and CON_Acm are significantly positive, within the range of 0.1338 to 0.9913 , lending construction validity to $C O N$ as a representative conditional conservatism measure. Nonetheless, the Pearson (Spearman) correlation between CON_Skew and CON_Acm is only $0.0018(0.0623)$, with the former statistically insignificant, which is not necessarily inappropriate since they gauge conditional conservatism from different dimensions: CON_Skew measures conservatism arising from earnings and operating accruals, while $C O N \_A c m$ captures conservatism arising from non-operating accruals. In addition, all Pearson and Spearman correlations of conditional conservatism measures with total accruals (TCA) are significantly negative, whereas those with accrual quality $(A c c)$ are significantly positive. This suggests that accounting-based conditional conservatism measures convey information about $T C A$ and $A C C$, but such information is not exactly the same as (and therefore cannot be subsumed by) that contained in total accruals and accrual quality of firms.

\begin{tabular}{|c|c|c|c|c|c|c|c|c|c|c|c|}
\hline \multicolumn{12}{|c|}{ Panel A: Summary Statistics } \\
\hline & $C O N$ & CON_Sken & CON_Acm & $T C A$ & $A c c$ & IRisk & ERisk & Size & Beta & $B M$ & Momentum \\
\hline Mean & -0.5035 & -1.0155 & 0.0085 & 0.0099 & 0.0534 & 0.0278 & -0.0063 & 2411.3615 & 1.2276 & 0.6252 & 0.1570 \\
\hline STD & 0.7700 & 0.2000 & 1.5200 & 0.1200 & 0.0500 & 0.0400 & 0.1200 & 12724.7500 & 0.3500 & 0.4400 & 0.5900 \\
\hline Q1 & -0.5780 & -1.1477 & -0.0231 & -0.0316 & 0.0224 & 0.0061 & -0.0544 & 55.9520 & 0.9648 & 0.3256 & -0.1667 \\
\hline Median & -0.5129 & -1.0303 & 0.0116 & 0.0080 & 0.0379 & 0.0170 & -0.0076 & 228.4739 & 1.1726 & 0.5167 & 0.0667 \\
\hline Q3 & -0.4291 & -0.8726 & 0.0425 & 0.0546 & 0.0664 & 0.0362 & 0.0393 & 1007.6076 & 1.4421 & 0.7952 & 0.3403 \\
\hline \multicolumn{12}{|c|}{ Panel B: Correlation Matrix } \\
\hline & $C O N$ & CON_Sken & CON_Acm & $T C A$ & $A c c$ & IRisk & ERisk & Size & Beta & $B M$ & Momentum \\
\hline CON & 1 & 0.1338 & 0.9913 & -0.0068 & 0.2244 & 0.0174 & 0.2947 & -0.0054 & 0.0236 & -0.0005 & 0.0016 \\
\hline CON_Skew & $v \mathbf{0 . 9 1 2 9}$ & 1 & 0.0018 & -0.0318 & 0.2552 & 0.0663 & 0.0681 & -0.0426 & 0.1595 & 0.0434 & 0.0255 \\
\hline CON_Acm & 0.4001 & 0.0623 & 1 & -0.0027 & 0.0493 & -0.0158 & 0.2887 & 0.0002 & 0.0027 & -0.0063 & -0.0017 \\
\hline$T C A$ & -0.0560 & -0.0375 & -0.0386 & 1 & -0.0451 & -0.0254 & $-\mathbf{0 . 3 0 3 6}$ & -0.0018 & 0.0184 & -0.1140 & 0.0112 \\
\hline$A c c$ & 0.2620 & 0.2780 & 0.0547 & -0.0198 & 1 & 0.0419 & 0.0185 & -0.0650 & 0.3004 & -0.0714 & 0.0119 \\
\hline IRisk & 0.0546 & 0.0942 & -0.0699 & 0.0095 & 0.1154 & 1 & 0.0054 & $-\mathbf{0 . 1 1 8 0}$ & 0.0588 & 0.3537 & 0.0653 \\
\hline ERisk & 0.1447 & 0.0629 & 0.2484 & -0.3270 & 0.0026 & -0.0112 & 1 & 0.0234 & 0.0099 & 0.0022 & 0.0268 \\
\hline Size & -0.1047 & -0.1442 & 0.0564 & 0.0221 & -0.2798 & -0.7671 & 0.0448 & 1 & -0.1202 & -0.1248 & -0.0019 \\
\hline Beta & 0.1474 & 0.1531 & 0.0518 & 0.0198 & 0.3271 & 0.0808 & -0.0340 & -0.2068 & 1 & 0.0114 & 0.0331 \\
\hline$B M$ & 0.0093 & 0.0305 & -0.0622 & -0.1314 & -0.0880 & 0.3620 & -0.0090 & -0.4294 & -0.0036 & 1 & 0.0619 \\
\hline Momentum & $\imath \mathbf{- 0 . 0 0 5 1}$ & -0.0162 & 0.0213 & 0.0019 & -0.0717 & 0.0018 & 0.0412 & 0.1026 & -0.0527 & 0.0472 & 1 \\
\hline
\end{tabular}

Table 1. Descriptive statistics for conditional conservatism and firm characteristic variables

Description: This table reports descriptive statistics for conditional conservatism measures and firm characteristic variables for the sample period of January 1986 to December 2008. Panel A shows summary statistics, and Panel B 
presents Pearson and Spearman correlations among these variables in the upper and lower triangles, respectively. Highlighted numbers are statistically significant at the 10\% level. Variable definitions are available in Sections 3 and 4.

\subsection{Hedging Portfolio Analysis Results}

Table 2 reports the hedging portfolio results for the average excess returns adjusted for cash flow news and abnormal returns represented by alphas as well as other measures that have influences on the expected stock returns or equity cost. We construct five $C O N$-sorted portfolios rebalanced each month, with portfolio 1 (5) representing observations with the smallest (largest) $C O N$. The average cash flow news adjusted excess return (Ret) and three abnormal return measures (CAPM alpha, 3-factor alpha, 4-factor alpha) all increase monotonically across CON portfolios, with average mean differences between the top and bottom portfolios as $0.0053,0.0044,0.0048$, and 0.0056 , respectively, all statistically significant at the $1 \%$ confidence level. A similar pattern is observed for Mom. In contrast, total accrual (TCA) declines monotonically with $C O N$, with an average of 0.0181 for portfolio 1 and 0.0005 for portfolio 5 . The mean difference of -0.0176 is statistically significant, suggesting that $C O N$ is negatively correlated with $T C A$, consistent with evidence in Table 1 . The pattern for accrual quality Acc, although non-monotonic, generally exhibits a positive relation with $C O N$ where the mean difference between portfolios 1 and 5 is 0.0338 , statistically significant at the $1 \%$ confidence level. Overall, Table 2 provides evidence that a higher $C O N$ is associated with higher expected returns (alphas or cash flow news adjusted excess returns), implying that larger conditional conservatism increases the cost of equity. Moreover, $C O N$ is shown to be significantly correlated with return momentum, total accruals, and accrual quality, indicating a need to control for these variables in multivariate cross-sectional regressions.

Table 2. Conditional conservatism-sorted portfolio analysis for average monthly cash flow news adjusted excess returns, alphas, momentum, total accruals, and accrual quality

\begin{tabular}{lccccccc}
\hline Portfolio & Ret & CAPM alpha & 3-factor alpha & 4-factor alpha & Momentum & TCA & Acc \\
\hline 1 & 0.0074 & 0.0031 & 0.0015 & 0.0030 & 0.1354 & 0.0181 & 0.0431 \\
2 & 0.0088 & 0.0044 & 0.0027 & 0.0041 & 0.1425 & 0.0132 & 0.0402 \\
3 & 0.0096 & 0.0049 & 0.0035 & 0.0053 & 0.1511 & 0.0129 & 0.0455 \\
4 & 0.0108 & 0.0058 & 0.0047 & 0.0062 & 0.175 & 0.0093 & 0.0569 \\
5 & 0.0127 & 0.0074 & 0.0063 & 0.0085 & 0.1772 & 0.0005 & 0.0769 \\
$(5-1)$ & 0.0053 & 0.0044 & 0.0048 & 0.0056 & 0.0418 & -0.0176 & 0.0338 \\
$t$-statistic & $(3.96)^{* * *}$ & $(3.70)^{* * *}$ & $(4.63)^{* * *}$ & $(4.87)^{* * * *}$ & $(5.60)^{* * *}$ & $(-23.68)^{* * * *}$ & $(40.75)^{* * * *}$ \\
\hline
\end{tabular}

Description: The table compares cash flow news adjusted excess returns, abnormal returns (alphas), momentum, total accruals, and accrual quality across portfolios formed on conditional conservatism $(C O N)$ for a sample of 62,833 observations of firms listed on the NYSE, NASDAQ, and AMEX with available CON measures over the period of January 1986 to December 2008. At the end of each month, firm-month observations are assigned into five portfolios based on the firm's most recent $C O N$ known four months prior to the current date. Portfolio 1 (5) contains firms with the smallest (largest) CON. Average differences between the top and bottom portfolios are reported in the row (5-1). The $t$-statistics for these differences are computed with a Newey and West (1987) correction. Ret refers to return excluding cash flow news and risk free rate, CAPM alpha, 3-factor alpha, and 4-factor alpha refer to abnormal returns from CAPM, Fama-French three-factor model, and Fama-French-Carhart four-factor model, respectively, TCA is total accruals (Sloan, 1996) and Acc is accrual quality (Kim \& Qi, 2010).

\subsection{Firm-Level Fama-MacBeth Regression Results}

Table 3 presents results for the Fama-MacBeth cross-sectional regressions of monthly cash flow news adjusted excess returns on $C O N$ and other firm risk characteristics including Beta, Size, BM, Mom, TCA, and Acc. Following Kim and Qi (2010), we also include Low_Priced, an indicator for low-priced shares along with Acc. Panels A and B show results without and with controls for Fama and French (1997) industry effects, respectively.

Consistent with results from the portfolio analysis, cross-sectional regression loadings on $C O N$ are consistently positive and significant, with coefficients ( $t$-statistics) of 0.0138 (3.54) and 0.0098 (3.32) in univariate regressions, without and with controlling for industry effects, respectively (Note 12). After Beta, Size, and BM are added as further controls, CON coefficients remain significantly positive, with corresponding coefficients ( $t$-statistics) of 0.0091 (3.42) and 0.0063 (2.77) in Panels A and B, respectively. Moreover, CON's effect on the cost of equity is not subsumed by either Mom, TCA, or Acc when they enter into the regressions individually or collectively, suggesting that $C O N$ provides incremental information beyond that from momentum, total accruals, and accrual quality. Therefore, results in Table 3 reconfirm that conditional conservatism is positively related to the cost of equity capital, which cannot be captured by standard risk factors and is not contributable to total accruals and/or accrual quality effects. The relation between 
conditional conservatism and the cost of equity is also robust to industrial characteristics.

Table 3. Fama-MacBeth regressions of monthly cash flow news adjusted excess returns on conditional conservatism

\begin{tabular}{|c|c|c|c|c|c|c|c|c|c|}
\hline Model & CON & Beta & Size & $B M$ & Momentum & $T C A$ & $A c c$ & L Priced & \\
\hline \multirow[t]{2}{*}{1} & 0.0138 & & & & & & & & 0.0017 \\
\hline & $(3.54)^{* * *}$ & & & & & & & & \\
\hline \multirow[t]{2}{*}{2} & 0.0091 & 0.0029 & -0.0014 & 0.0022 & & & & & 0.0256 \\
\hline & $(3.42)^{* * *}$ & $(0.92)$ & $(-2.75)^{* * *}$ & $(2.46)^{* *}$ & & & & & \\
\hline \multirow[t]{2}{*}{3} & 0.0088 & 0.0019 & -0.0015 & 0.0022 & 0.0022 & & & & 0.0325 \\
\hline & $(3.41)^{* * *}$ & $(0.68)$ & $(-3.01)^{* * *}$ & $(2.52)^{* *}$ & $(1.24)$ & & & & \\
\hline \multirow[t]{2}{*}{4} & 0.0085 & 0.0031 & -0.0014 & 0.0017 & & -0.0171 & & & 0.0267 \\
\hline & $(3.24)^{* * *}$ & $(1.01)$ & $(-2.78)^{* * *}$ & $(1.97)^{* *}$ & & $(-5.88)^{* * *}$ & & & \\
\hline \multirow[t]{2}{*}{5} & 0.0115 & 0.0023 & -0.0021 & 0.0026 & & & 0.0324 & -0.0158 & 0.0345 \\
\hline & $(5.24)^{* * *}$ & $(0.77)$ & $(-4.85)^{* * *}$ & $(3.45)^{* * *}$ & & & $(2.45)^{* *}$ & $(-8.46)^{* * *}$ & \\
\hline \multirow[t]{2}{*}{6} & 0.0107 & 0.0018 & -0.0022 & 0.0023 & 0.0000 & -0.0169 & 0.0295 & -0.0158 & 0.0419 \\
\hline & $(4.94)^{* * *}$ & $(0.65)$ & $(-5.11)^{* * *}$ & $(2.97)^{* * *}$ & $(0.03)$ & $(-5.78)^{* * *}$ & $(2.38)^{* *}$ & $(-9.30)^{* * *}$ & \\
\hline \multicolumn{10}{|c|}{ Panel B: Regressions with Industry Dummies } \\
\hline Model & CON & Beta & Size & $B M$ & Momentum & $T C A$ & $A c c$ & Low_Priced & Avg. Adj. R-square \\
\hline \multirow[t]{2}{*}{1} & 0.0098 & & & & & & & & 0.0367 \\
\hline & $(3.32)^{* * *}$ & & & & & & & & \\
\hline \multirow[t]{2}{*}{2} & 0.0063 & 0.0025 & -0.0013 & 0.0025 & & & & & 0.0535 \\
\hline & $(2.77)^{* * *}$ & $(0.95)$ & $(-2.72)^{* * *}$ & $(3.65)^{* * *}$ & & & & & \\
\hline \multirow[t]{2}{*}{3} & 0.0061 & 0.0018 & -0.0014 & 0.0026 & 0.0008 & & & & 0.0587 \\
\hline & $(2.73)^{* * *}$ & $(0.74)$ & $(-2.97)^{* * *}$ & $(3.77)^{* * *}$ & $(0.48)$ & & & & \\
\hline \multirow[t]{2}{*}{4} & 0.0059 & 0.0027 & -0.0013 & 0.0021 & & -0.0151 & & & 0.0544 \\
\hline & $(2.59)^{* * *}$ & (1.04) & $(-2.75)^{* * *}$ & $(3.07)^{* * *}$ & & $(-5.75)^{* * *}$ & & & \\
\hline \multirow[t]{2}{*}{5} & 0.0106 & 0.0032 & -0.0023 & 0.0025 & & & 0.0103 & -0.0159 & 0.0626 \\
\hline & $(5.01)^{* * *}$ & $(1.26)$ & $(-5.35)^{* * * *}$ & $(3.89)^{* * *}$ & & & $(0.96)$ & $(-8.90)^{* * * *}$ & \\
\hline \multirow[t]{2}{*}{6} & 0.0099 & 0.0028 & -0.0024 & 0.0023 & -0.0013 & -0.0156 & 0.0087 & -0.0164 & 0.0682 \\
\hline & $(4.71)^{* * *}$ & (1.19) & $(-5.60)^{* * *}$ & $(3.54)^{* * *}$ & $(-0.85)$ & $(-5.62)^{* * * *}$ & $(0.85)$ & $(-10.00)^{* * *}$ & \\
\hline
\end{tabular}

Description: This table presents estimation results for Fama-MacBeth regressions of monthly cash flow news adjusted excess returns against conditional conservatism $(C O N)$ and other firm characteristics including Beta, Size, BM, Momentum, TCA, Acc, and a low-priced return indicator variable Low_Priced for the period of January 1986 to December 2008. The reported estimates are time-series averages of coefficients from 276 monthly cross-sectional regressions. The $t$-statistics are calculated from Newey and West (1987) standard errors of these monthly averages. Panel A reports results without controlling for Fama and French (1997) industry effect, whereas Panel B reports results after controlling for industry effect by adding dummies for the Fama-French industries. Monthly cash flow news adjusted excess return is calculated as the raw return less cash flow news and the risk free return proxied by U.S. one-month T-bill rate. Beta is estimated following the procedure in Fama and French (1992). Size is the natural log of market capitalization. $B M$ is the natural $\log$ of the ratio of book value of equity to market value of equity. We match Beta, Size, and BM measures with return data following Fama and French (1992). Momentum is an 11-month return in the prior-year omitting the most recent month. $C O N$ is the average of firm-year conditional conservatism measure CON_Acm and CON_Skew, TCA is total accruals (Sloan, 1996), Acc is the accrual quality measure used in Kim and Qi (2010) and Ogneva (2012). We match annual estimates of CON, TCA, and Acc with monthly stock returns in the next 12 months starting four months after the fiscal year-end. The low-priced return indicator is set to 1 if returns are computed using two adjacent prices less than $\$ 5$ and 0 otherwise. The main models used in Panels $\mathrm{A}$ and $\mathrm{B}$ are estimated using model (5) described in Section 3.

\subsection{Portfolio-Level 2SCSR Results}

To further confirm conditional conservatism's impact on the cost of equity, we conduct the 2SCSR analysis at the portfolio-level, which is less affected by firm-specific characters that may contaminate the underlying relation considered. Table 4 reports estimation results for models (6) to (9). Panel A presents the first-stage time-series regressions of monthly portfolio excess stock returns adjusted for cash flow news on the $C O N$ factor $(R C O N)$, Fama and French (1993) three factors $\left(R_{M}-R_{F}, S M B\right.$, and $\left.H M L\right)$, and Carhart (1997) momentum factor (UMD). Factor loadings 
on $R C O N$ are significantly positive, with magnitudes ( $t$-statistics) of 0.4725 (4.16) when the three Fama-French factors are controlled and 0.3814 (3.41) when the momentum factor is further added.

Panel B reports results for the second-stage cross-sectional regressions of mean cash flow news adjusted excess portfolio returns on factor loadings estimated from the first stage. The coefficients for the factor loadings on RCON, $\beta_{R C O N}$, are significantly positive with magnitudes ( $t$-statistics) of 0.0051 (3.42) and 0.0055 (3.49) when loadings on the Fama and French (1993) three factors and Carhart (1997) four factors are controlled, respectively. The last column indicates that when $\beta_{R C O N}$ is included, the average adjusted $R^{2}$ jumps from 0.4170 to 0.7566 for the three-factor model and from 0.4086 to 0.7530 for the four-factor model. Therefore, evidence from the 2 SCSR analysis provides further support for the enhancing effect of conditional conservatism on the cost of equity. In the next section, we explore the proposed information precision and information asymmetry effects that contribute to the positive conditional conservatism and cost of equity relation.

Table 4. Portfolio-level two-stage cross-sectional regressions

\begin{tabular}{lccccccc}
\hline Panel A: & First-stage Time-series Regressions of Portfolio Returns on Factor Returns & & \\
\hline Model & Intercept & $R_{M}-R_{F}$ & $S M B$ & HML & UMD & RCON & Adj. R-square \\
\hline 1 & 0.0053 & 1.0925 & 0.8475 & 0.2868 & & & 0.7626 \\
& $(4.54)^{* * *}$ & $(42.25)^{* * *}$ & $(11.83)^{* * *}$ & $(4.05)^{* * *}$ & & & \\
2 & 0.0031 & 1.0292 & 0.7242 & 0.3330 & & 0.4725 & 0.7857 \\
& $(3.37)^{* * *}$ & $(31.14)^{* * *}$ & $(13.71)^{* * *}$ & $(4.92)^{* * *}$ & & $(4.16)^{* * *}$ & \\
3 & 0.0077 & 1.0457 & 0.8665 & 0.2272 & -0.2305 & & 0.7834 \\
& $(6.38)^{* * * *}$ & $(41.16)^{* * *}$ & $(11.96)^{* * *}$ & $(3.06)^{* * *}$ & $(-11.26)^{* * *}$ & & \\
4 & 0.0056 & 1.0003 & 0.7647 & 0.2718 & -0.2023 & 0.3814 & 0.8024 \\
& $(6.74)^{* * *}$ & $(30.52)^{* * *}$ & $(14.38)^{* * *}$ & $(3.83)^{* * *}$ & $(-11.70)^{* * *}$ & $(3.41)^{* * *}$ & \\
\hline
\end{tabular}

Panel B: Second-stage Cross-sectional Regressions of Portfolio Returns on Factor Loadings

\begin{tabular}{lccccccc}
\hline Model & Intercept & $\beta_{R M-R F}$ & $\beta_{S M B}$ & $\beta_{H M L}$ & $\beta_{U M D}$ & $\beta_{R C O N}$ & Adj. R-square \\
\hline 1 & 0.0250 & -0.0184 & 0.0061 & 0.0051 & & & 0.4170 \\
& $(2.60)^{* * *}$ & $(-2.42)^{* *}$ & $(2.21)^{* *}$ & $(1.95)^{*}$ & & & \\
2 & 0.0282 & -0.0180 & -0.0049 & 0.0091 & & 0.0051 & 0.7566 \\
& $(4.52)^{* * *}$ & $(-3.66)^{* * *}$ & $(1.82)$ & $(4.93)^{* * *}$ & & $(3.42)^{* * * *}$ & \\
3 & 0.0263 & -0.0214 & 0.0045 & 0.007 & -0.0090 & & 0.4086 \\
& $(2.68)^{* * * *}$ & $(-2.53)^{* *}$ & $(1.33)$ & $(1.98)^{* * *}$ & $(-0.61)$ & & \\
4 & 0.0275 & -0.0159 & -0.0044 & 0.0079 & 0.0050 & 0.0055 & 0.7530 \\
& $(4.36)^{* * *}$ & $(-2.90)^{* * *}$ & $(-1.59)$ & $(3.45)^{* * *}$ & $(-0.51)$ & $(3.49)^{* * *}$ &
\end{tabular}

Description: This table shows results of Fama-French 25 portfolio-level two-stage cross-sectional regressions for a sample over the 1986-2008 period. Panel A reports average factor loadings and adjusted $R^{2}$ of the first-stage time-series regressions of monthly portfolio cash flow news adjusted excess returns against the three Fama-French factors, a momentum factor, and a conservatism factor RCON, using models (6) and (7) described in Section 3. We construct RCON as the return on a zero-investment portfolio by buying the top 20 percent of firms and selling the bottom 20 percent of firms in terms of $C O N$. Panel B reports estimated coefficients for the second-stage cross-sectional regressions of excess portfolio returns on portfolio factor loadings estimated from the first stage, according to models (8) and (9) in Section 3.

\subsection{Information Precision and Information Asymmetry Effects of Conditional Conservatism and Its Relation with the Cost of Equity}

We move on to investigate how conditional conservatism affects the cost of equity through its information precision effect and information asymmetry effect. We first employ a portfolio approach to examine how they mediate the relation between conditional conservatism and the cost of equity. Specifically, we construct five $C O N$-based portfolios and check the levels of information asymmetry IRisk and information precision (about negative earnings shocks) ERisk in each portfolio. If high-CON portfolios on average have significantly higher IRisk and/or ERisk, then we can conclude 
that conditional conservatism can generally elevate the information asymmetry and/or information precision of negative earnings shocks. We then use the following Fama-MacBeth model and its simplified variations to investigate both effects in multivariate regressions:

$$
\begin{aligned}
R_{i t+1}-R_{F t+1}=\alpha+\beta_{1} \operatorname{CON}_{i t}+ & \beta_{2} \text { Beta }_{i t}+\beta_{3} \text { Size }_{i t}+ \\
& \beta_{4} B M_{i t}+\beta_{5} \text { IRisk }_{i t}+\beta_{6} \text { ERisk }_{i t} \\
& + \text { Industry_Dummies }+\mu_{i t+1}
\end{aligned}
$$

where $R_{i t+1}, R_{F t+1}$, Beta $_{i t}$, Size $_{i t}$, and $C O N_{i t}$ are defined as in model (5) and Industry_Dummies represents the Fama and French (1997) industry classifications. If $C O N$ affects the cost of equity capital via information asymmetry and/or earnings downside risk, then adding IRisk and/or ERisk should weaken the relation as reflected in the magnitude and significance level of the $C O N$ coefficient.

Table 5 reports results from the portfolio analysis and Fama-MacBeth regressions for testing how conditional conservatism affects the cost of equity through the information asymmetry and information precision effects. Panel A presents mean values of the information asymmetry measure IRisk and the measure for information precision of negative earnings shocks ERisk in different $C O N$-sorted portfolios, with portfolio 1 (5) containing observations with the smallest (largest) CON. IRisk increases non-monotonically with CON, revealing an asymmetric "V" pattern. It falls from 0.0303 in portfolio 1 to 0.0284 in portfolio 2 , suggesting that conditional conservatism at lower levels serves to reduce information asymmetry. Then, IRisk increases monotonically to 0.0350 in portfolio 5 , implying that at higher levels, CON increases information asymmetry. The mean difference of IRisk between portfolios 5 and 1 is 0.0047 , statistically significant at the $1 \%$ confidence level. Therefore, $C O N$ is nonlinearly associated with information asymmetry, but on average, a positive relation dominates, suggesting that high conditional conservatism can in general increase the cost of equity capital via enhancing information asymmetry as suggested by Gow et al. (2011) and Lambert et al. (2012). The information precision of negative earnings shocks measure ERisk increases monotonically with CON, and the mean difference ( $t$-statistic) between the top and bottom portfolios is 0.0567 (38.95), suggesting that conditional conservatism does increase the precision of information regarding negative earnings shocks. Since earnings downside risk induces a higher cost of equity (Luo et al., 2014), this evidence suggests that conditional conservatism may increase the cost of equity capital through enhancing the precision of negative earnings news.

Panel B of Table 5 presents estimated results for the Fama-MacBeth regressions using model (10) with fixed industry effects. In all models, the coefficients on conditional conservatism CON become much smaller than those in Panel B of Table 3 where IRisk and ERisk are not controlled. In particular, the CON coefficients ( $t$-statistics) drop to 0.0053 (2.13) and 0.0049 (2.22), respectively, after adding IRisk and ERisk as further controls compared with the figure of 0.0063 (2.77) in Panel B of Table 3 where only the three Fama-French factors are controlled for. Importantly, the CON coefficient falls to 0.0041 when both IRisk and ERisk are controlled, and it is only marginally significant with a $t$-statistic of 1.68. Combined, the findings indicate that information asymmetry and information precision of negative earnings shocks partially account for the effect of conditional conservatism on the cost of equity, and they subsume a larger portion of loading on conditional conservatism when both are included in the regression model. This evidence lends support to the notion that the positive relation between conditional conservatism and the cost of equity operates (at least partially) through the effects of information asymmetry and information precision of negative earnings shocks.

Table 5. Conditional conservatism-sorted portfolio analysis and Fama-MacBeth regression of cash flow news adjusted excess returns on conditional conservatism, information asymmetry, and information precision about negative earnings

\begin{tabular}{|c|c|c|c|c|c|c|c|}
\hline \multicolumn{8}{|c|}{ Panel A: Portfolio Analysis } \\
\hline & \multicolumn{4}{|c|}{ IRisk } & \multicolumn{3}{|c|}{ ERisk } \\
\hline 1 & \multirow{2}{*}{\multicolumn{4}{|c|}{0.0303}} & \multicolumn{3}{|c|}{-0.0313} \\
\hline 2 & & & & & \multicolumn{3}{|c|}{-0.0109} \\
\hline 3 & \multicolumn{4}{|c|}{$\begin{array}{l}0.0284 \\
0.0310\end{array}$} & \multicolumn{3}{|c|}{-0.0108} \\
\hline 4 & \multicolumn{4}{|c|}{0.0341} & \multicolumn{3}{|c|}{-0.0063} \\
\hline 5 & \multicolumn{4}{|c|}{0.0350} & \multicolumn{3}{|c|}{0.0254} \\
\hline$(5-1)$ & \multirow{2}{*}{\multicolumn{4}{|c|}{0.0047}} & \multirow{2}{*}{\multicolumn{3}{|c|}{$\begin{array}{c}0.0567 \\
(38.95)^{* * * *}\end{array}$}} \\
\hline$t$-statistic & \multicolumn{2}{|c|}{$(24.11)^{* * *}$} & & & & & \\
\hline \multicolumn{8}{|c|}{ Panel B: $\quad$ Fama-MacBeth Regressions with Industry Dummies } \\
\hline Model & CON & Beta & Size & $B M$ & IRisk & ERisk & Avg. Adj. R-square \\
\hline 1 & $\begin{array}{l}0.0053 \\
(2.13)^{* *}\end{array}$ & $\begin{array}{l}0.0036 \\
(1.29)\end{array}$ & $\begin{array}{c}-0.0004 \\
(-0.65)\end{array}$ & $\begin{array}{c}0.0022 \\
(2.92)^{* * * *}\end{array}$ & $\begin{array}{c}0.1522 \\
(4.13)^{* * *}\end{array}$ & & 0.0545 \\
\hline 2 & $\begin{array}{l}0.0049 \\
(2.22)^{* *}\end{array}$ & $\begin{array}{l}0.0021 \\
(0.80)\end{array}$ & $\begin{array}{c}-0.0012 \\
(-2.73)^{* * * *}\end{array}$ & $\begin{array}{l}0.0025 \\
(3.63)^{* * * *}\end{array}$ & & $\begin{array}{l}0.0152 \\
(5.10)^{* * *}\end{array}$ & 0.0555 \\
\hline 3 & $\begin{array}{l}0.0041 \\
(1.68)^{*}\end{array}$ & $\begin{array}{c}0.0034 \\
(1.18) \\
\end{array}$ & $\begin{array}{c}-0.0004 \\
(-0.85) \\
\end{array}$ & $\begin{array}{c}0.0024 \\
(3.01)^{* * * *}\end{array}$ & $\begin{array}{c}0.1595 \\
(4.06)^{* * *}\end{array}$ & $\begin{array}{c}0.0145 \\
(4.32)^{* * *}\end{array}$ & 0.0561 \\
\hline
\end{tabular}
shocks. 
Description: This table presents estimation results for testing the information asymmetry and information precision effects on the conditional conservatism and cost of equity relation. Panel A reports results from portfolio analyses for information asymmetry proxy IRisk and earnings downside risk measure ERisk. At the end of each month, firm-month observations are assigned into one of five portfolios based on a firm's most recent $C O N$ known four months prior to the current date. Portfolio 1 (5) contains firms with the smallest (largest) CON. Average differences in IRisk and ERisk between the top and bottom portfolios are reported in row (5-1). The $t$-statistics for these differences are computed with a Newey-West (1987) correction. Panel B shows results for Fama-MacBeth regressions (model (10) of Section 4) of future monthly cash flow news adjusted excess returns on CON, IRisk, ERisk, and other firm characteristics (Beta, Size, $B M$ ). The reported estimates are time-series averages of the coefficients on CON from 276 monthly cross-sectional regressions. Reported $t$-statistics are calculated from Newey and West (1987) standard errors of these monthly averages.

\subsection{SOX and the Relation between Conditional Conservatism and the Cost of Equity}

Thus far, we have examined how the effects of conditional conservatism on information asymmetry and precision of negative earnings shocks affect its association with the cost of equity. If these channels play a role, then the passage of SOX provides an ideal setting wherein their influences should change and thus induce alternation in the relation between conditional conservatism and the cost of equity capital (Chang, Fernando, \& Liao, 2009; Skaife, Collins, Kinney, \& LaFond, 2009; Amir, Guan, \& Livne, 2010) (Note 13). The SOX Act enacted in 2003 is a response to allegations of accounting irregularities in Enron and other firms, and it is intended in part to improve the overall financial reporting quality of all public firms, enhance information precision, mitigate information asymmetry between firms and investors, and improve market efficiency. Whereas several prior studies document increased conditional conservatism in the post-SOX period (e.g., Lobo \& Zhou, 2006), our design lends itself to further detecting potential reductions in equity cost arising from reduced information asymmetry after SOX, thus complementing prior findings. With regard to the information precision effect, since SOX increases information transparency for all firms, the cross-sectional information precision effect of negative earnings shocks conveyed via conditional conservatism may be weakened by the nationwide heightened information precision. This connotes a reduced effect of conservatism on the cost of equity in the post-SOX period, ceteris paribus. The SOX passage also decreases information asymmetry and shrinks potential mispricing, which further abates the potential information asymmetry effect of conditional conservatism on the cost of equity. Based on these arguments, we expect a weakened association between conditional conservatism and the cost of equity after the SOX enactment. This serves to provide additional support for the informational effects of conditional conservatism on increasing the cost of equity in the pre-SOX period.

Figure 1 graphically presents the per-year average cash flow news adjusted excess returns to conditional conservatism-sorted hedging portfolios. A striking pattern is observed whereby hedging returns are consistently positive for most years during the pre-SOX period from 1986 to 2002. The returns become negative from 2004 through 2008, the post-SOX period, with generally smaller magnitudes and variability compared with the pre-SOX period. The spike in 2003 is consistent with enhanced revelations of bad news associated with the implementation of SOX.

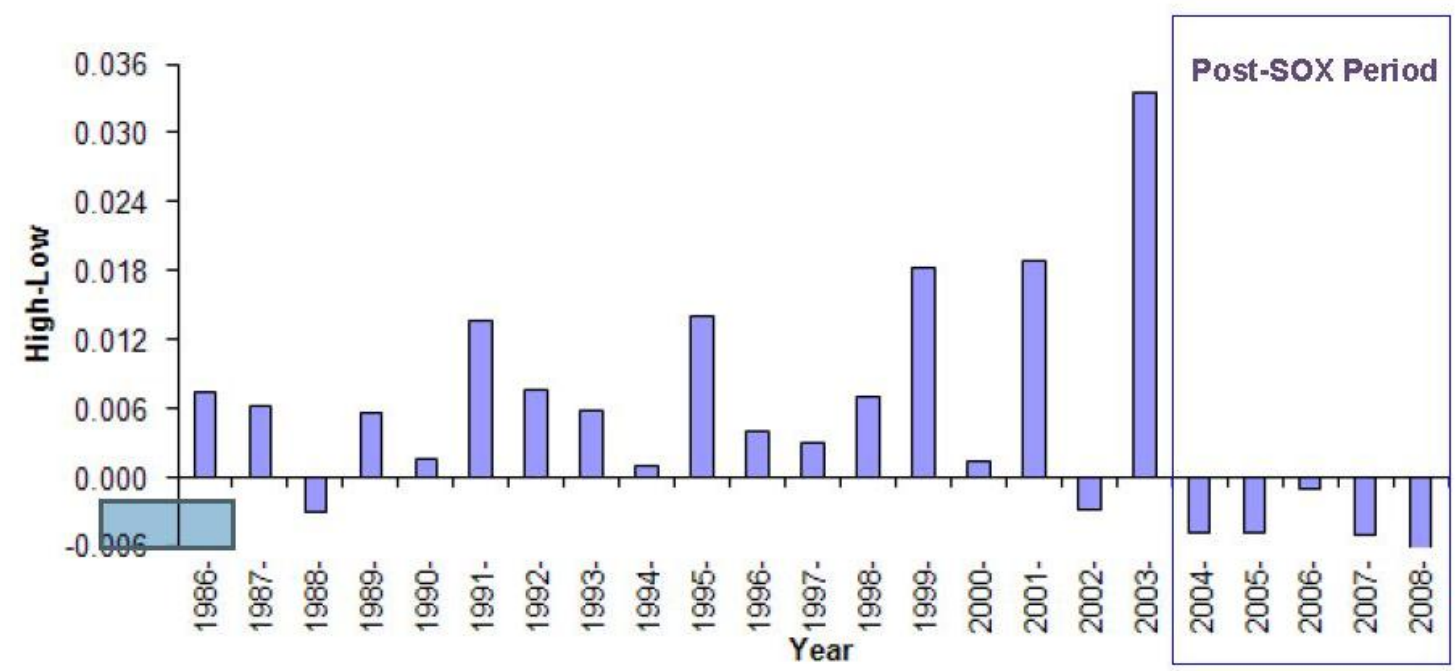

Figure 1. Mean differences in cash flow news adjusted excess return for conditional conservatism-sorted hedging portfolios by year

To further examine the influence of SOX on the association between conditional conservatism and the cost of equity, we conduct firm-level Fama-MacBeth regressions of cash flow news adjusted excess returns on conditional conservatism 
CON separately for the pre- and post-SOX periods. We report results in Panels A and B of Table 6. To avoid possible noises from transient market reactions to the SOX regulation, we omit the years when SOX was passed (2002) and implemented (2003). Panel A reveals that the positive relation between conditional conservatism and the cost of equity is driven primarily by observations from the pre-SOX period. In particular, loadings on CON are positive and significant in all regressions before the implementation of SOX. Panel B indicates that CON coefficients are generally negative and/or insignificant in the post-SOX period, consistent with Figure 1. In summary, results in pre- and post-SOX periods collectively corroborate the notion that the passage of SOX diminishes the information asymmetry and information precision effects of conditional conservatism on the cross-section of stock returns, resulting in a weak relation between conditional conservatism and the cost of equity.

Table 6. SOX and Fama-MacBeth regressions of cash flow news adjusted excess returns on conditional conservatism and firm characteristics with industry dummies

\begin{tabular}{|c|c|c|c|c|c|c|c|c|c|c|c|}
\hline \multirow{2}{*}{$\frac{\text { Panel A: }}{\text { Model }}$} & \multicolumn{11}{|c|}{ Fama-MacBeth Regressions in the Pre-SOX Period before 2002 (1986.01-2001.12) } \\
\hline & CON & Beta & Size & $B M$ & Momentum & $T C A$ & $A c c$ & Low_Priced & IRisk & ERisk & Ave. Adj. R-square \\
\hline 1 & $\begin{array}{c}0.0124 \\
(3.87)^{\text {**** }}\end{array}$ & & & & & & & & & & 0.0334 \\
\hline 2 & $\begin{array}{c}0.0095 \\
(3.62)^{* * *}\end{array}$ & $\begin{array}{c}0.0032 \\
(1.10)\end{array}$ & $\begin{array}{l}-0.0011 \\
(-1.80)^{*}\end{array}$ & $\begin{array}{c}0.0028 \\
(3.20)^{* * *}\end{array}$ & & & & & & & 0.0505 \\
\hline 3 & $\begin{array}{c}0.0094 \\
(3.63)^{* * *}\end{array}$ & $\begin{array}{c}0.0023 \\
(0.89)\end{array}$ & $\begin{array}{l}-0.0013 \\
(-2.02)^{* *}\end{array}$ & $\begin{array}{c}0.0027 \\
(3.17)^{* * *}\end{array}$ & $\begin{array}{l}0.0030 \\
(1.72)^{*}\end{array}$ & & & & & & 0.0554 \\
\hline 4 & $\begin{array}{c}0.0088 \\
(3.36)^{* * * *}\end{array}$ & $\begin{array}{l}0.0035 \\
(1.19)\end{array}$ & $\begin{array}{l}-0.0012 \\
(-1.82)^{*}\end{array}$ & $\begin{array}{c}0.0022 \\
(2.55)^{* *}\end{array}$ & & $\begin{array}{c}-0.0198 \\
(-6.02)^{\text {**** }}\end{array}$ & & & & & 0.0515 \\
\hline 5 & $\begin{array}{c}0.0124 \\
(5.06)^{* * *}\end{array}$ & $\begin{array}{c}0.0032 \\
(1.15)\end{array}$ & $\begin{array}{l}-0.0020 \\
(-3.64)^{\text {*** }}\end{array}$ & $\begin{array}{c}0.0029 \\
(3.51)^{* * *}\end{array}$ & & & $\begin{array}{c}0.0230 \\
(1.56)\end{array}$ & $\begin{array}{c}-0.0154 \\
(-6.72)^{* * *}\end{array}$ & & & 0.0611 \\
\hline 6 & $\begin{array}{c}0.0086 \\
(2.93)^{* * *}\end{array}$ & $\begin{array}{l}0.0046 \\
(1.45)\end{array}$ & $\begin{array}{c}-0.0002 \\
(-0.31)\end{array}$ & $\begin{array}{c}0.0026 \\
(2.75)^{* * *}\end{array}$ & & & & & $\begin{array}{c}0.0816 \\
(3.55)^{* * * *}\end{array}$ & & 0.0499 \\
\hline 7 & $\begin{array}{c}0.0082 \\
(3.24)^{* * *}\end{array}$ & $\begin{array}{c}0.0028 \\
(0.92)\end{array}$ & $\begin{array}{l}-0.0011 \\
(-1.80)^{*}\end{array}$ & $\begin{array}{c}0.0028 \\
(3.14)^{* * *}\end{array}$ & & & & & & $\begin{array}{c}0.0207 \\
(5.84)^{* * *}\end{array}$ & 0.0523 \\
\hline 8 & $\begin{array}{c}0.0105 \\
(3.44)^{* * *}\end{array}$ & $\begin{array}{c}0.0061 \\
(2.18)^{* *} \\
\end{array}$ & $\begin{array}{l}-0.0013 \\
(-1.94)^{*} \\
\end{array}$ & $\begin{array}{l}0.0017 \\
(1.69)^{*} \\
\end{array}$ & $\begin{array}{c}0.0004 \\
(0.20) \\
\end{array}$ & $\begin{array}{c}-0.0207 \\
(-4.80)^{* * *} \\
\end{array}$ & $\begin{array}{c}0.0115 \\
(0.72) \\
\end{array}$ & $\begin{array}{c}-0.0206 \\
(-9.43)^{* * *}\end{array}$ & $\begin{array}{c}0.1434 \\
(5.47)^{* * * *} \\
\end{array}$ & $\begin{array}{c}0.0163 \\
(3.57)^{* * *} \\
\end{array}$ & 0.0684 \\
\hline Panel B & 3: Fama & -MacBeth & Regressio & ns in the $P$ & Dost-SOX Per & iod after 20 & $003(2004$ & 4.01-2008.12) & & & \\
\hline Model & CON & Beta & Size & $B M$ & Momentum & $T C A$ & $A c c$ & Low_Priced & IRisk & ERisk & Ave. Adj. R-square \\
\hline 1 & $\begin{array}{c}-0.0073 \\
(-1.31)\end{array}$ & & & & & & & & & & 0.0449 \\
\hline 2 & $\begin{array}{c}-0.0062 \\
(-1.60)\end{array}$ & $\begin{array}{c}-0.0046 \\
(-1.14)\end{array}$ & $\begin{array}{l}-0.0005 \\
(-0.91)\end{array}$ & $\begin{array}{l}0.0011 \\
(0.96)\end{array}$ & & & & & & & 0.0559 \\
\hline 3 & $\begin{array}{c}-0.0063 \\
(-1.58)\end{array}$ & $\begin{array}{c}-0.0045 \\
(-1.18)\end{array}$ & $\begin{array}{c}-0.0007 \\
(-1.11)\end{array}$ & $\begin{array}{l}0.0012 \\
(1.05)\end{array}$ & $\begin{array}{c}-0.0009 \\
(-0.31)\end{array}$ & & & & & & 0.0604 \\
\hline 4 & $\begin{array}{c}-0.0058 \\
(-1.55)\end{array}$ & $\begin{array}{c}-0.0043 \\
(-1.06)\end{array}$ & $\begin{array}{c}-0.0006 \\
(-0.95)\end{array}$ & $\begin{array}{l}0.0011 \\
(0.99)\end{array}$ & & $\begin{array}{c}-0.0012 \\
(-0.28)\end{array}$ & & & & & 0.0565 \\
\hline 5 & $\begin{array}{l}0.0046 \\
(-1.19)\end{array}$ & $\begin{array}{l}-0.0025 \\
(-0.63)\end{array}$ & $\begin{array}{c}-0.0022 \\
(-4.35)^{\text {**** }}\end{array}$ & $\begin{array}{l}0.0010 \\
(0.86)\end{array}$ & & & $\begin{array}{c}-0.0145 \\
(-1.51)\end{array}$ & $\begin{array}{l}-0.0212 \\
(-7.57)^{* * *}\end{array}$ & & & 0.0599 \\
\hline 6 & $\begin{array}{l}-0.0068 \\
(-1.71)^{*}\end{array}$ & $\begin{array}{c}-0.0043 \\
(-1.09)\end{array}$ & $\begin{array}{l}0.0003 \\
(-0.57)\end{array}$ & $\begin{array}{l}0.0007 \\
(0.62)\end{array}$ & & & & & $\begin{array}{c}0.3126 \\
(2.33)^{* *}\end{array}$ & & 0.0595 \\
\hline 7 & $\begin{array}{c}-0.0057 \\
(-1.51)\end{array}$ & $\begin{array}{c}-0.0046 \\
(-1.14)\end{array}$ & $\begin{array}{c}-0.0007 \\
(-1.17)\end{array}$ & $\begin{array}{c}0.0010 \\
(0.83)\end{array}$ & & & & & & $\begin{array}{c}-0.0002 \\
(-0.04)\end{array}$ & 0.0572 \\
\hline 8 & $\begin{array}{l}0.0027 \\
(-0.71)\end{array}$ & $\begin{array}{c}-0.0014 \\
(-0.38)\end{array}$ & $\begin{array}{c}-0.0004 \\
(-0.73)\end{array}$ & $\begin{array}{c}0.0007 \\
(0.60)\end{array}$ & $\begin{array}{l}-0.0057 \\
(-2.02)^{* *}\end{array}$ & $\begin{array}{c}-0.0015 \\
(-0.35)\end{array}$ & $\begin{array}{c}-0.0060 \\
(-0.61)\end{array}$ & $\begin{array}{c}-0.0258 \\
(-8.98)^{* * *}\end{array}$ & $\begin{array}{c}0.6457 \\
(4.36)^{\text {**** }}\end{array}$ & $\begin{array}{l}0.0059 \\
(-0.89)\end{array}$ & 0.0714 \\
\hline
\end{tabular}

Description: This table presents estimation results for Fama-MacBeth regressions of monthly cash flow news adjusted excess returns on conditional conservatism (CON), total accruals (TCA), accrual quality (Acc) (along with a low-priced return indicator variable Low_Priced), information asymmetry (IRisk), earnings downside risk (ERisk), and firm characteristics including Beta, Size, and BM, plus controls for dummies for Fama and French (1997) industries. Panel A reports average regression coefficients for the period of January 1986 to December 2001, a period before SOX; Panel B reports average coefficients for the period of January 2004 to December 2008, a period after SOX. Reported t-statistics are calculated from Newey and West (1987) standard errors of these monthly averages. 


\section{Robustness Checks}

\subsection{Alternative Conditional Conservatism Measures}

To check the robustness of our main findings, we use several alternative measures for conditional conservatism. We first separately use $C O N \_S k e w, C O N \_A c m$, and the ranking of $C O N$, with results qualitatively unchanged. Then we use two other conditional conservatism proxies Skew and CONA as introduced in Section 3 and also find qualitatively similar results. Nevertheless, one may still be concerned about whether our results still hold when using the traditional accounting-based conditional conservatism measures in Basu (1997) and doubt the validity of our findings. To address this issue, we try the more classical measure based on the asymmetric persistence of net income in Basu (1997). We have to make two extensions to the original measure in Basu (1997) to better fit in our research: (i) to derive a pure accounting-based conservatism measure, we use total assets or sales as the deflator for net income instead of using stock price; and (ii) to avoid a potentially serious survival bias, we estimate the model of net income changes or levels below by quarterly data rather than annual data because at least 12 observations are needed to comparatively and accurately estimate the model. We use a rolling window of 16 quarterly observations to estimate models (11) and (12) below.

$$
\begin{aligned}
& \Delta N I_{i t}=\beta_{0}+\beta_{1} D D_{i t-1}+\beta_{2} \Delta N I_{i t-1}+\beta_{3} D D_{i t-1 *} \Delta N I_{i t-1}+\varepsilon_{i t+1} \\
& N I_{i t}=\tau_{0}+\tau_{1} D_{i t-1}+\tau_{2} N I_{i t-1}+\tau_{3} D_{i t-1} * N I_{i t-1}+\phi_{i t+1}
\end{aligned}
$$

where $\Delta N I_{i t}\left(N I_{i t}\right)$ refers to the ratio of quarterly net income changes (quarterly net income) to lagged corresponding values in total assets $\triangle R O A_{i t}\left(R O A_{i t}\right)$, or the ratio of quarterly net income changes (quarterly net income) to lagged corresponding values in sales $\triangle R O S_{i t}\left(R O S_{i t}\right) . D D_{i t-l}$ is the indicator for negative $\Delta N I_{i t-l}$, while $D_{i t-l}$ is the indicator for negative $N I_{i t-1}$. We use the rankings of the estimated coefficients $\beta_{3}$ or $\tau_{3}$ as the conditional conservatism measure because using quarterly earnings data yields noisy coefficient estimations. When $\triangle R O A_{i t}$ or $R O A_{i t}$ is used, the estimated conditional conservatism measures from models (11) and (12) are denoted Basu_ $\triangle R O A_{i t}$ and $B a s u \_R O A_{i t}$, respectively. When $\triangle R O S_{i t}$ or $R O S_{i t}$ is used, we denote the estimated conditional conservatism measures as Basu_ $\triangle R O S_{i t}$ and $B a s \__{-} R O S_{i t}$, respectively. Table 7 reports the estimation results for our baseline Fama-MacBeth regression tests using these alternative conservatism measures. In all univariate and multivariate regressions, Basu_ $\triangle R O A_{i t}, B a s u_{-} \Delta R O S_{i t}$, $B a s \__{-} R O A_{i t}$, and $B a s u_{-} R O S_{i t}$ are significantly positively associated with the cost of equity capital except for the last model where Basu_ROS ${ }_{i t}$ is used in the multivariate regression. Therefore, our testing results are generally robust to the classical accounting-based conditional conservatism measures based on the asymmetric earnings persistence.

Table 7. Alternative conditional conservatism measures and Fama-MacBeth regression for the relation between

\begin{tabular}{|c|c|c|c|c|c|c|c|c|c|c|c|c|}
\hline Model & Basu_ $\triangle R O A$ & Basu__ROS & Basu_ROA & Basu_ROS & Beta & Size & $B M$ & \multicolumn{2}{|c|}{ MomentunTCA } & $A c c$ & Low_Priced & Avg. Adj. R-square \\
\hline \multirow[t]{2}{*}{1} & 0.0038 & & & & & & & & & & & 0.0378 \\
\hline & $(3.60)^{* * *}$ & & & & & & & & & & & \\
\hline \multirow[t]{2}{*}{2} & 0.0037 & & & & 0.003 & $7-0.0022$ & 0.0019 & -0.0016 & -0.0158 & $0.012 i$ & $7-0.0153$ & 0.0692 \\
\hline & $(3.99)^{* * *}$ & & & & $(1.61)$ & $(-5.15)^{* * *}$ & $(3.00)^{* *}$ & $*^{* *}(-1.03)$ & $(-5.66)^{*}$ & **1(1.18) & $(-9.49)^{* * *}$ & \\
\hline \multirow[t]{2}{*}{3} & & 0.0029 & & & & & & & & & & 0.0372 \\
\hline & & $(3.28)^{* * *}$ & & & & & & & & & & \\
\hline \multirow[t]{2}{*}{4} & & 0.0032 & & & 0.003 & $7-0.0022$ & 0.0019 & -0.0016 & -0.0172 & $0.015 z$ & -0.0152 & 0.0692 \\
\hline & & $(3.88)^{* * * *}$ & & & (1.61) & $(-5.04)^{* * *}$ & $(2.93)^{* *}$ & **; $(-1.02)$ & $(-6.01)^{*}$ & *** (1.39) & $(-9.35)^{* * *}$ & \\
\hline \multirow[t]{2}{*}{5} & & & 0.0015 & & & & & & & & & 0.0376 \\
\hline & & & $(1.68)^{*}$ & & & & & & & & & \\
\hline \multirow[t]{2}{*}{6} & & & 0.0018 & & 0.003 & $8-0.0022$ & 0.0020 & -0.0016 & -0.0155 & $0.015 i$ & $7 \quad-0.0152$ & 0.0691 \\
\hline & & & $(2.13)^{* *}$ & & (1.66) & ${ }^{*}(-5.07)^{* * *}$ & $(3.22)^{* * *}$ & $* *(-1.02)$ & $(-5.58)^{*}$ & **" $(1.42)$ & $(-9.39)^{* * *}$ & \\
\hline \multirow[t]{2}{*}{7} & & & & 0.0016 & & & & & & & & 0.0373 \\
\hline & & & & $(1.64)^{*}$ & & & & & & & & \\
\hline \multirow[t]{2}{*}{8} & & & & 0.0014 & 0.003 & $8-0.0022$ & 0.0019 & -0.0015 & -0.0171 & $0.016 c$ & ( -0.0150 & 0.0693 \\
\hline & & & & $(1.50)$ & $(1.65)$ & ${ }^{*}(-5.01)^{* * *}$ & $(3.03)^{* *}$ & *** $(-0.99)$ & $(-5.92)^{*}$ & ***(1.44) & $(-9.25)^{* * *}$ & \\
\hline
\end{tabular}
conditional conservatism and cash flow news adjusted excess returns

Description: This table presents estimation results for univariate and multivariate Fama-MacBeth regressions (after controlling for industry effect) of monthly cash flow news adjusted excess returns on alternative conditional conservatism measures extending the measurement in Basu (1997). Construction of Basu-based conditional 
conservatism measures are detailed in Section 5. Definitions of other variables are the same as in Tables 3 and 6. Reported t-statistics are calculated from Newey and West (1987) standard errors.

\subsection{Alternative Cost of Capital Measures}

For alternative measures of the cost of equity, we extend Botosan et al. (2011) and use the analyst forecast error as an approximation for cash flow news, which is computed as the difference between the reported annual earnings per share less its analyst forecast deflated by the stock price. Using the newly constructed cost of equity measure, we find that the baseline results are similar to the reported.

\subsection{Alternative Measures for Information Precision and Information Asymmetry}

We also use the following alternative measures for information asymmetry: (i) the annual average of daily high and low spread over the 12 months prior to the current fiscal year-end, HLSpread, calculated following Corwin and Schultz (2011); and (ii) private information trading Itrade, calculated following Llorente et al. (2002) and Ferreira and Laux (2007). These treatments do not qualitatively change the estimation results. For alternative earnings downside risk proxies that reflect the information precision effect, we further adopt earnings volatility and the root lower partial moment of ROA AERisk as substitute measures. When these proxies are used, results are consistent with those reported in the main tests.

\subsection{Alternative Estimation Methods}

In alternative asset pricing tests, we used pooled OLS regressions instead of the Fama-MacBeth method. We also follow McInnis (2010) and drop all return-months in which a firm announces quarterly earnings to reduce the possibility that improper adjustments for cash flow news may bias the results. We further add the liquidity beta as a control for the liquidity effect. All these schemes deliver findings that are qualitatively similar to the reported. Finally, to address the concern that the results for the post-SOX period are driven by the price plump and liquidity depletion during the 2007 to 2008 financial crisis, we drop the years of 2007 and 2008 from our post-SOX sample period, replicate Panel B of Table 6 , and achieve qualitatively unchanged results.

\section{Conclusion}

Prior studies examine the effect of conditional conservatism on the cost of equity mainly based on the theory that improved information quality reduces covariance between a firm's stock return and the market return, thus decreasing the cost of equity. The empirical evidence, however, is mixed and not consistent. In this study, we propose that improved information quality regarding bad earnings news as induced by conditional conservatism entails two informational consequences: more precise information about negative earnings shocks and heightened information asymmetry, both of which may generate economy-wide or market-wide effects and increase the cost of equity. Using accounting-based conditional conservatism measures and the cash flow news adjusted stock returns as the proxy for the cost of equity, we find a significantly positive relation between conditional conservatism and the cost of equity capital, and document evidence that such positive relation (at least partially) operates via the effects of information asymmetry and information precision about negative earnings shocks. We also find that the positive association between conditional conservatism and the cost of equity disappears in the post-SOX period, consistent with the mitigated cross-sectional power of the information precision and information asymmetry effects of conditional conservatism engendered by the nationwide improved information quality after SOX.

This study supplements prior literature that documents an insignificant or negative relation between conditional conservatism and the cost of equity. Our findings also augment the SOX literature by documenting a diminution of the influence of conditional conservatism in the direction of increasing the cost of capital after the implementation of SOX, and connote the importance of considering regulation-induced economy-wide effects. Moreover, the evidence holds implications for ongoing deliberations regarding the costs and benefits of conservatism, and further implies that conditional conservatism imposes costs on both equity investors and managers, thus pointing to a legitimate rationale for managers to disfavor conditional conservatism, which is largely neglected in the literature.

\section{Acknowledgements}

We are grateful for the comments and advices from Pingyang Gao, Chaoli Guo, Tao Lin, Yan Luo, Xingrong Qiang, Tony Jun Ruan, Jing Wang, Yanyan Wang, participants and discussants at the 2011 Canadian Academic Accounting Association Annual Meetings, the 2011 Asian Academic Accounting Association Annual Meetings, and the 2011 International Symposium on Empirical Accounting Research. We appreciate research assistance from Chen Chen and Ariel Liao.

\section{References}

Accounting Principles Board. (1970). Statement No. 4: Basic concepts and accounting principles underlying financial statements of business enterprises. Stamford, CT: Financial Accounting Standards Board [FASB]. 
Akins, B., Ng, J., \& Verdi, R. (2012). Investor competition over information and the pricing of information asymmetry. The Accounting Review, 87(1), 35-58.

Armstrong, C., Guay, W., \& Weber, J. (2010). The role of information and financial reporting in corporate governance and debt contracting. Journal of Accounting and Economics, 50(2-3), 179-234.

Armstrong, C., Core, J., Taylor, D., \& Verrecchia, V. (2011). When does information asymmetry affect the cost of capital? Journal of Accounting Research, 49(1), 1-40.

Amir, E., Guan, Y., \& Livne, G. (2010). Auditor independence and the cost of capital before and after Sarbanes-Oxley: The case of newly issued public debt. European Accounting Review, 19(4), 633-664.

Ball, R., Jayaraman, S., \& Shivakumar, L. (2012). Mark-to-market accounting and information asymmetry in banks. Working paper, University of Chicago.

Basu, S. (1995). Conservatism and the asymmetric timeliness of earnings (Doctoral dissertation). University of Rochester, New York, USA.

Basu, S., (1997). The conservatism principle and the asymmetric timeliness of earnings. Journal of Accounting and Economics, 24(1), 3-37.

Botosan, C., Plumlee, M., \& Wen, H. (2011). The relation between expected returns, realized returns, and firm risk characteristics. Contemporary Accounting Research, 28(4), 1085-1122.

Callen, J., Segal, D., \& Hope, O-K. 2010. The pricing of conservative accounting and the measurement of conservatism at the firm-year level. Review of Accounting Studies, 15(1), 145-178.

Carhart, M. (1997). On the persistence of mutual fund performance. Journal of Finance, 52(1), 57-82.

Caskey, J., \& Peterson, K. (2009). On the estimation of the asymmetric timeliness of earnings: Inference and bias corrections. Working Paper, University of California at Los Angeles.

Chang, H., Fernando, G., \& Liao, L. (2009). Sarbanes-Oxley act, perceived earnings quality and cost of capital. Review of Accounting and Finance, 8(3), 216-231.

Chen, Q., Hemmer, T., \& Zhang, Y. (2007). On the relation between conservatism in accounting standards and incentives for earnings management. Journal of Accounting Research, 45(3), 541-565.

Corwin, S., \& Schultz, P. (2011). A Simple way to estimate bid-ask spreads from daily high and low prices. Journal of Finance, 67(2), 719-760.

Crawley, M. (2012). Macroeconomic consequences of accounting: The effect of accounting conservatism on macroeconomic indicators and the money supply. Working paper, Indiana University.

Demski, J., \& Feltham, G. (1994). Market response to financial reports. Journal of Accounting and Economics, 17(1-2): $3-40$.

Diamond, D., \& Verrecchia, R. (1991). Disclosure, liquidity, and the cost of capital. Journal of Finance, 46(4), 1325-1359.

Easley, D., Hvidkjaer, S., \& O’Hara, M. (2002). Is information risk a determinant of asset returns? Journal of Finance, 57(5), 2185-2221.

Easley, D., \& O’Hara, M. (2004). Information and the cost of capital. Journal of Finance, 59(4), $1553-1583$.

Fama, E., \& French, K. (1992). The cross-section of expected stock returns. Journal of Finance, 47(2), 427-465.

Fama, E., \& French, K. (1993). Common risk factors in the returns on stocks and bonds, Journal of Financial Economics, 33(1), 3-56.

Fama, E., \& French, K. (1997). Industry cost of equity. Journal of Financial Economics, 43(2), 153-193.

Fama, E., \& MacBeth, J. (1973). Risk, return and equilibrium: Empirical tests. Journal of Political Economy, 81(3), 607-636.

Fan, Q., \& Zhang, X. (2012). Accounting conservatism, aggregation, and information quality. Contemporary Accounting Research, 29(1), 38-56.

Ferreira, M., \& Laux, P. (2007). Corporate governance, idiosyncratic risk, and information flow, Journal of Finance, 62(2), 951-989.

Financial Accounting Standards Board. (1980). Statement of financial accounting concepts No. 2: Qualitative characteristics of accounting information. Stamford, CT: Financial Accounting Standards Board [FASB]. 
Francis, J., LaFond, R., Olsson, P., \& Schipper, K. (2004). Cost of equity and earnings attributes. The Accounting Review, 79(4), 967-1010.

Gao, P. (2011). A contracting approach to conservatism and earnings management. Working paper, University of Chicago.

Gao, P., \& Liang, P. (2011). Informational feedback effect, adverse selection, and the optimal disclosure policy. Working paper, University of Chicago.

Garcia Lara, J., Garcia Osma, B., \& Penalva, F. (2011). Conditional conservatism and cost of capital. Review of Accounting Studies, 16(2), 247-271.

Gigler, F., Kanodia, C., Sapra, H., \& Venugopalan, R. (2009). Accounting conservatism and the efficiency of debt contracts. Journal of Accounting Research, 47(3), 767-97.

Givoly, D., \& Hayn, C. (2000). The changing time-series properties of earnings, cash flows and accruals: Has financial reporting become more conservative? Journal of Accounting and Economics, 29(3), 287-320.

Gox, R., \& Wagenhofer, A. (2009). Optimal impairment rules. Journal of Accounting and Economics, 48(1), 2-16.

Gow, I., Taylor, D., \& Verrecchia, R. (2011). Earnings precision, information asymmetry, and the cost of capital: Evidence of information complementarities. Working paper, Harvard University.

Guay, W., \& Verrecchia, R. (2007). Conservative disclosure. Working paper, University of Pennsylvania.

Hughes, J., Liu, J., \& Liu, J. (2007). Information asymmetry, diversification, and cost of capital. The Accounting Review, 82(3), 705-730.

Jorgensen, B., Li, J., \& Sadkay, G. (2012). Earnings dispersion and aggregate stock returns. Journal of Accounting and Economics, 53(1-2), 1-20.

Johnstone, D. (In Press). The effect of information on uncertainty and the cost of capital. Contemporaneous Accounting Research.

Khan, M. (2008). Are accruals mispriced? Evidence from tests of an intertemporal capital asset pricing model. Journal of Accounting and Economics, 45(1), 55-77.

Khan, M., \& Watts, R. (2009). Estimation and empirical properties of a firm-year measure of accounting conservatism. Journal of Accounting and Economics, 48(2-3), 131-150.

Kim, B., \& Pevzner, M. (2010). Conditional accounting conservatism and future negative surprises: An empirical investigation. Journal of Accounting Public Policy, 29(4), 311-329.

Kim, D., \& Qi, Y. (2010). Accruals quality, stock returns, and macroeconomic conditions. The Accounting Review, 85(3), 937-978.

Kim, O., \& Verrecchia, R. (1991). Market reaction to anticipated announcements. Journal of Financial Economics, 30(2), 273-309.

Kothari, S., Shu, S., \& Wysocki, P. (2009). Do managers withhold bad news? Journal of Accounting Research, 47(1), 241-276.

LaFond, R., \& Roychowdhury, S. (2008). Managerial ownership and accounting conservatism. Journal of Accounting Research, 46(1), 101-135.

LaFond, R., \& Watts, R. (2008). The information role of conservatism. The Accounting Review, 83(2), 447-478.

Lambert, R., Leuz, C., \& Verrecchia, R. (2007). Accounting information, disclosure, and the cost of capital. Journal of Accounting Research, 45(2), 385-420.

Lambert, R., Leuz, C., \& Verrecchia, R. (2012). Information asymmetry, information precision, and the cost of capital. Review of Finance, 16(1), 1-29.

Lewellen, J., Nagel, S., \& Shanken, J. (2010). A skeptical appraisal of asset pricing tests. Journal of Financial Economics, 96(2), 175-194.

Li, X. (2010) Accounting conservatism and cost of capital: An international analysis. Working paper, Temple University.

Llorente, G., Michaely, R., Saar, G., \& Wang, J. (2002). Dynamic volume-return relation of individual stocks. Review of Financial Studies, 15(4), 1005-1047.

Lobo, G., \& Zhou, J., (2006). Did conservatism in financial reporting increase after the Sarbanes-Oxley Act? Initial evidence. Accounting Horizons, 20(1), 57-73. 
Louis, H., Lys, T., \& Sun, A. (2014). Conservatism and analyst earnings forecast bias. Working paper, Pennsylvania State University.

Luo, Y., Ma, M., \& Wu, F. (2014). Earnings downside risk. Working paper, Fudan University.

McInnis, J. (2010). Earnings smoothness, average returns, and implied cost of equity capital. The Accounting Review, 85(1), 315-341.

McNichols, M., \& Trueman, B. (1994). Public disclosures, private information collection, and short-term trading. Journal of Accounting and Economics, 17(1-2), 69-94.

Mensah, Y., Song, X., \& Ho, S. (2004). The effect of conservatism on analysts' annual earnings forecast accuracy and dispersion. Journal of Accounting, Auditing and Finance, 19(2), 159-183.

Nan, L., \& Wen, X. (2011). Conservatism's effects on capital structure efficiency and information quality. Working paper, University of Illinois at Chicago.

Newey, W., \& West, K. (1987). A simple, positive semi-definite, heteroskedasticity and autocorrelation consistent covariance matrix, Econometrica , 55(3), 703-708.

Ogneva, M. (2012). Accrual quality, realized returns, and expected returns: The importance of controlling for cash flow shocks. The Accounting Review, 87(4), 1415-1444.

Rogers, J., Skinner, D., \& Buskirk, A. (2009). Earnings guidance and market uncertainty. Journal of Accounting and Economics, 48(1), 90-109.

Ryan, S. (2006). Identifying conditional conservatism. European Accounting Review, 15(4), 511-525.

Skaife, H., Collins, D., Kinney, W., \& LaFond, R. (2009). The effect of SOX internal control deficiencies on firm risk and cost of equity. Journal of Accounting Research, 47(1), 1-43.

Sloan, R. (1996). Do stock prices fully reflect information in accruals and cash flows about future earnings? The Accounting Review, 71(3), 289-315.

Srivastava, T., \& Sunder, S. (2011). Timely loss recognition and the early termination of unprofitable projects. Working paper, Northwestern University.

Verrecchia, R. (2001). Essays on disclosure. Journal of Accounting and Economics, 32(1-3), 97-180.

Vuolteenaho, T. (2002). What drives firm-level stock returns? Journal of Finance, 57(1), 233-264.

Watts, R. (2003). Conservatism in accounting, Part I: Explanations and implications. Accounting Horizons, 17(3), 207-221.

Zhang, J. (2008). The contracting benefits of accounting conservatism to lenders and borrowers. Journal of Accounting and Economics, 45(1), 27-54.

\section{Notes}

Note 1. As guidance, the Financial Accounting Standards Board's Statement of Financial Accounting Concepts No. 2 (1980, para. 95) intones that "if two estimates of amounts to be received or paid in the future are about equally likely, conservatism dictates using the less optimistic estimate." The Accounting Principles Board (Statement No. 4, 1970, para. 171) observes that "managers, investors, and accountants have generally preferred that possible errors in measurement be in the direction of understatement rather than overstatement of net income and net assets. This has led to the convention of conservatism."

Note 2. In particular, Caskey and Petersen (2009) argue that the Basu (1997) measure uses the ratio of slope coefficients and thus may provide biased estimates because returns are impacted by expected future profits. Other market-based conditional conservatism measures, such as the C-score in Khan and Watts (2009), also share a similar weakness.

Note 3. Botosan et al. (2011) and Ogneva (2012) argue that cash flow news does not cancel out in large samples, and therefore, asset pricing tests may induce biases when future realized returns are used to proxy for expected returns.

Note 4. Akins et al. (2012), Armstrong et al. (2011), and Gow et al. (2011) also find that information asymmetry does not affect the cost of equity incremental to market risk if firms' stocks are traded in highly liquid and competitive markets.

Note 5. Callen et al. (2010) develop the CR ratio, a market-based conservatism measure, from the relation between conditional conservatism and cash flow news.

Note 6. Another measure for cash flow news is earnings forecast error (Botosan et al., 2011; Ogneva, 2012), which is 
not used in our main tests since it introduces estimation bias. However, in robustness checks, we use it as an alternative proxy for cash flow news and obtain similar results.

Note 7. We utilize accrual downside risk because it is the source of earnings downside risk and has better prediction power for negative fundamental operational shocks (Luo et al., 2014).

Note 8 . Henceforth, we use the term return or equity return to represent the excess returns adjusted for cash flow news, provided that no confusion arises.

Note 9. $T C A_{i t}=\left(\Delta C A_{i t}-\Delta C L_{i t}-\triangle C a s h_{i t}+\triangle S T D E B T_{i t}+\Delta T P_{i t}-D P_{i t}\right) / A T A_{i t}$, where $\Delta C A_{i t}$ is the one-year change in current assets, $\triangle C L_{i t}$ is the one-year change in current liabilities, $\triangle C a s h_{i t}$ is the one-year change in cash, $\triangle S T D E B T_{i t}$ is the one-year change in current liabilities, $\Delta T P_{i t}$ is the income tax payable, $D P_{i t}$ is the depreciation expense, and $A T A_{i t}$ is the average total assets over $t-1, t$, and $t+1$.

Note 10. The accrual quality measure $A c c$ is defined as the decile ranking of the ratio of the standard deviation of the residual from the regression $T C A_{i t}=\alpha_{t}+\beta_{0 t} A T A_{i t}+\beta_{1 t} O C F_{i t-1}+\beta_{2 t} O C F_{i t}+\beta_{3 t} O C F_{i t+1}+\beta_{4 t} \Delta R E V_{i t}+\beta_{5 t} P P E_{i t}+\varepsilon_{i t}$, where $T C A_{i t}$ is total current accruals for year $t$ as defined above, $O C F_{i t}$ is operating cash flow for year $t, \triangle R E V_{i t}$ is the one-year change in revenues, and $P P E_{i t}$ is the property, plant and equipment for year $t$.

Note 11. The mean (median) of total accruals TCA is 0.0099 (0.0080), which is higher than the documented negative values in Sloan (1996) due to different sampling periods. The sampling period in this study is from 1986 to 2008, whereas the period in Sloan (1996) is from 1962 to 1991. As we extend the sampling period back to 1962, the mean and median of total accruals become negative, in line with Sloan's (1996) evidence.

Note 12. Rigorously speaking, model 1 in Panel B is not a univariate regression because it also includes industry dummy variables. We call it univariate for simplicity.

Note 13. Chang et al. (2009) report that SOX reduces the cost of equity capital in general by improving financial reporting quality; Skaife et al. (2009) document that SOX reduces equity cost via mandatory disclosures of internal control weaknesses; Amir et al. (2010) likewise argue that SOX enhances the negative relation between auditor independence and the cost of debt capital proxied by bond ratings and yields.

\section{$(c)$ EY}

This work is licensed under a Creative Commons Attribution 3.0 License. 